\title{
A new vanilla species from Costa Rica closely related to $\mathrm{V}$. planifolia (Orchidaceae)
}

José B. AZOFEIFA-BOLAÑOS ${ }^{1}$, L. Rodolphe GIGANT ${ }^{2}$, Mayra NICOLÁS-GARCÍA ${ }^{3}$, Marc PIGNAL $^{4}$, Fabiola B. TAVARES-GONZÁLEZ ${ }^{5}$, Eric HÁGSATER ${ }^{6}$, Gerardo A. SALAZAR-CHÁVEZ ${ }^{7}$, Delfino REYES-LÓPEZ ${ }^{8}$, Fredy L. ARCHILA-MORALES ${ }^{9}$, José A. GARCÍA-GARCÍA ${ }^{10}$, Denis da SILVA ${ }^{11}$, Agathe ALLIBERT ${ }^{12}$, Frank SOLANOCAMPOS ${ }^{13}$, Guadalupe del Carmen RODRÍGUEZ-JIMENES ${ }^{14}$, Amelia PANIAGUAVÁSQUEZ ${ }^{15}$, Pascale BESSE ${ }^{16}$, Araceli PÉREZ-SILVA ${ }^{17}$ \& Michel GRISONI ${ }^{18, *}$

${ }^{1,15}$ Universidad Nacional de Costa Rica, Instituto de Investigación y Servicios Forestales, Heredia, Costa Rica.

${ }^{2,11,16}$ Université de La Réunion, UMR PVBMT, Saint Denis, La Réunion, France.

${ }^{3,17}$ Instituto Tecnológico de Tuxtepec, Tuxtepec (Oax), Mexico.

${ }^{4}$ Muséum national d'Histoire naturelle, UMR 7205 - ISYEB CNRS-MNHN-UPMC-EPHE, Paris, France.

${ }^{5,14}$ Instituto Tecnológico de Veracruz, Veracruz (Ver), Mexico. ${ }^{6}$ Herbario AMO, México (DF), Mexico.

${ }^{7}$ Universidad Autónoma de México, Instituto de Biología, México (DF), Mexico.

${ }^{8}$ Benemérita Universidad Autónoma de Puebla, Facultad de Ingeniería Agro-hidráulica, Teziutlán (Pue), Mexico.

${ }^{9}$ Herbario BIGU, Universidad de San Carlos de Guatemala, Guatemala.

${ }^{10}$ Universidad Nacional de Costa Rica, Escuela de Ciencias Agrarias, Heredia, Costa Rica. ${ }^{12,18}$ CIRAD, UMR PVBMT, Saint Pierre, La Réunion, France.

${ }^{13}$ Universidad Nacional de Costa Rica, Laboratorio de Biotecnología de Plantas, Heredia, Costa Rica.

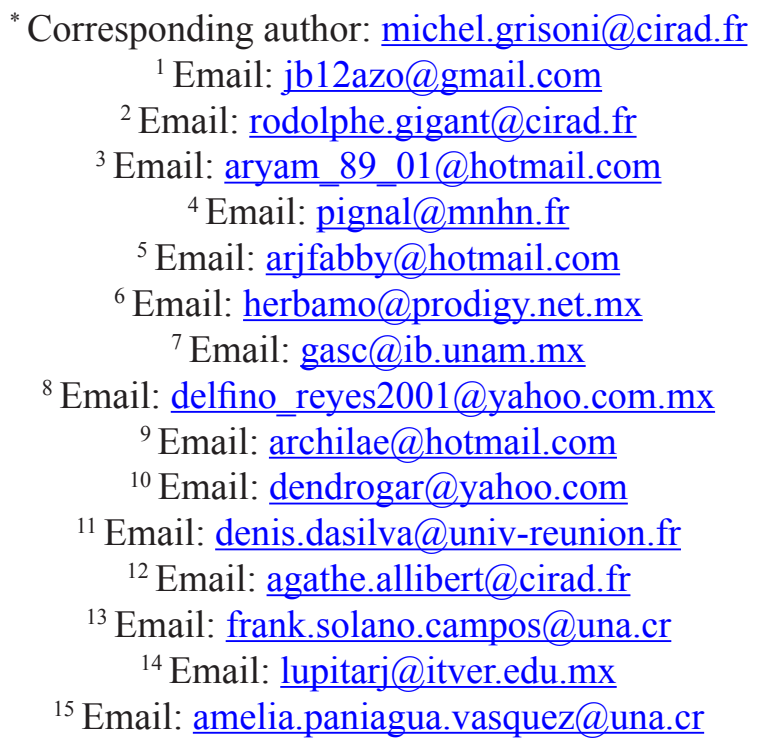




\title{
${ }^{16}$ Email: pascale.besse@univ-reunion.fr \\ ${ }^{17}$ Email: apsilva30@hotmail.com
}

\begin{abstract}
We describe a new vanilla species growing in sympatry with Vanilla planifolia Jacks. ex Andrews (Orchidaceae) in the province of Limón, Caribbean coast of Costa Rica. The morphology of the reproductive and vegetative organs observed on vines cultivated under shade-house, the nuclear (Internal Transcribed Spacer) and plastid (matK) nucleotide sequences, as well as the contents of aromatic compounds measured in ripe fruits, show that this species is close to but distinct from $V$. planifolia. The name $V$. sotoarenasii M.Pignal, Azofeifa-Bolaños \& Grisoni sp. nov. is proposed for this new Vanilla species endemic in Costa Rica. It is especially distinguished from $V$. planifolia by a reduction of about $30 \%$ of the size of the fruits and flowers, by a divergence of ITS sequences for at least two species-conserved nucleotides compared to seven other species of the V. planifolia group, and by the presence of anisic compounds and low content of phenolic compounds (including vanillin) in the fruits. These results confirmed the extension of the area of distribution of V. planifolia southward to Costa Rica, where a recent speciation process occurred. Because of its particular agronomic and aromatic properties, $V$. sotoarenasii sp. nov. could represent a valuable biological resource for the vanilla industry.
\end{abstract}

Keywords. Barcoding, Costa Rica, Limón, radiation, Vanilla planifolia, V. sotoarenasii.

Azofeifa-Bolaños J.B., Gigant L.R., Nicolás-García M., Pignal M., Tavares-González F.B., Hágsater E., SalazarChávez G.A., Reyes-López D., Archila-Morales F.L., García-García J.A., da Silva D., Allibert A., Solano-Campos F., Rodríguez-Jimenes G.d.C., Paniagua-Vásquez A., Besse P., Pérez-Silva A. \& Grisoni M. 2017. A new vanilla species from Costa Rica closely related to V. planifolia (Orchidaceae). European Journal of Taxonomy 284 : 1-26. http://dx.doi.org/10.5852/ejt.2017.284

\section{Introduction}

The Vanilla genus, Vanilla Plum. ex Miller (Miller 1754), belongs to the subfamily Vanilloideae, tribe Vanillinae (Cameron 2010). It is an ancient group of tropical orchids that originated in America about 70 million years ago and differentiated in America, Africa and Asia (Ramírez et al. 2007; Bouétard et al. 2010). The classification of the species of Vanilla was recently reviewed by Soto Arenas \& Cribb (2010), who divided the genus into two subgenera, Vanilla and Xanata Soto Arenas \& P.J.Cribb, and further split the subgenus Xanata into two sections Xanata and Tethya Soto Arenas \& P.J.Cribb. Currently, about 110 Vanilla species are reported and clustered into 20 groups (Portères 1954; Soto Arenas \& Cribb 2010; Cameron 2011; Pansarin et al. 2012). The V. planifolia group is the most important by the number of species (16) and, economically, because it contains the commercial species V.planifolia Jacks. ex Andrews (Andrews 1808) and $V$. $\times$ tahitensis J.W.Moore (Moore 1933), the aromatic fruits of which provide the vanilla flavor used by the food and perfumes industries. The taxonomy of the species from Mexico and Central America was reviewed by Soto Arenas \& Dressler (2010) on the basis of their morphology and Internal Transcribed Spacer (ITS) DNA sequences. Recently, two new species have been described in the region, V. esquipulensis Archila \& Chiron (Archila \& Chiron 2012) in Guatemala and V. rivasii Molineros, R.T.González, Flanagan \& J.T.Otero (Molineros-Hurtado et al. 2014) in Chocó, northern Colombia, plus two more in French Guiana, V. inornata Sambin \& Chiron (Sambin \& Chiron 2015) and V. aspericaulis Sambin \& Chiron (Sambin \& Chiron 2015).

Ten out of the 17 species recorded in Mexico and Central America have been reported in Costa Rica (Soto Arenas \& Dressler 2010), namely: V. costaricensis Soto Arenas (Soto Arenas \& Dressler 2010), V. dressleri Soto Arenas (Soto Arenas \& Dressler 2010), V. hartii Rolfe (Rolfe 1899), V. helleri A.D.Hawkes (Heller \& Hawkes 1966), V. inodora Schiede (Schiede 1829), V. odorata C.Presl (Pres1 
1827), V. planifolia, V. pompona Schiede (Schiede 1829), V. sarapiquensis Soto Arenas (Soto Arenas \& Dressler 2010) and V. trigonocarpa Hoehne (Hoehne 1944).

During surveys carried out in Costa Rica since 2012 (Azofeifa-Bolaños et al. 2014) abundant populations of vanilla which did not fit any species previously described in the country were observed in Limón Province (Caribbean coast of Costa Rica). This vanilla, called "vanilla Limón" (VanL), had strong morphological similarities with a vanilla accession collected in Cahuita (Limón, Costa Rica) in 1993, referenced Pignal 396b (P00075132) in the herbarium of the Muséum national d'Histoire naturelle in Paris, P (herbarium acronym following Thiers continuously updated). Living specimens of this accession were preserved in the Emmanuel Liais park (Cherbourg-en-Cotentin, France) under accession number CH554, and subsequently in the Biological Resources Centre (BRC) Vatel (Saint Pierre, La Réunion) under accession number CR0068, and were tentatively classified as $V$. aff. planifolia.

Molecular approaches have enhanced plant taxonomy by allowing reliable genealogy-based classifications (Besse 2014). In the last decade, nuclear, mitochondrial and chloroplastic DNA sequencing has been used to study plant diversity and resolve taxonomic positions in all plant families, including the puzzling group of vanilloid orchids (Cameron 2009, 2010; Soto Arenas \& Dressler 2010).

The aim of this study was thus to investigate the taxonomic status of VanL by using complementary approaches involving morphology of reproductive and vegetative organs, molecular barcoding and the accumulation of secondary metabolites in fruits.

\section{Material and methods}

\section{Plant and DNA samples}

The plant samples used in this study were obtained from field surveys carried out in Costa Rica, Mexico and Guatemala, supplemented with lyophilized plant materials preserved in the Mexican National Collection (Reyes-López et al. 2014), the BRC Vatel (Roux-Cuvelier \& Grisoni 2010), and DNA from the herbarium of the Instituto Chinoin, AMO (Thiers continuously updated).

The survey in Costa Rica was conducted between November 2012 and March 2016 in the entire country. Prospections were targeted on areas where vanilla were recorded based on herbarium specimen information and consulting orchid experts, local guides, and earlier project experiences, among others. The material was collected according to permit number 061-2013 issued on 12 Jun. 2013 by National System of Conservation Areas (SINAC) of the Ministry of Environment and Energy (MINAE).

All plant and DNA samples analyzed in this study are listed in Table 1.

\section{Morphological traits}

To compare the morphology of vegetative and reproductive organs of VanL to those of V. planifolia, the following traits were measured on plants cultivated in controlled conditions in BRC Vatel in La Réunion: length and greater width of the third and fourth leaves, diameter and length of the third inter-node, length and width of the tube, length of the ovary, length and width of the dorsal sepal. Measurements were carried out on two to six plants per accession grown under shade-house in November, which is the optimum vegetative growth and flowering period in La Réunion. From 14 to 30 fresh organs were measured per accession according to the availability of material. Length and weight of fruits were also measured at maturity (in July). We used the experimental tool "collaboratoire" of the national French infrastructure e-ReColNat (ANR-11-INBS-0004) for specimen comparisons. 
Table 1. Identification and origin of the accessions of species of Vanilla Plum. ex Miller used in this study. [continued on next 3 pages]

\begin{tabular}{|c|c|c|c|c|c|}
\hline Code & Species & $\begin{array}{c}\text { Country of } \\
\text { origin }\end{array}$ & Depository & Locus & $\begin{array}{c}\text { Code in collection / } \\
\text { voucher }\end{array}$ \\
\hline bahi0071 & V. bahiana & Brazil & VATEL & $m a t \mathrm{~K}$ & CR0071 \\
\hline bahi0086 & V. bahiana & Brazil & VATEL & ITS \& matK & CR0086 \\
\hline bahi0098 & V. bahiana & Brazil & VATEL & ITS & CR0098 \\
\hline bahi0099 & V. bahiana & Brazil & VATEL & ITS \& matK & CR0099 \\
\hline bahi0668 & V. bahiana & Brazil & VATEL & $\operatorname{mat} \mathrm{K}$ & CR0668 \\
\hline caly-01 & V. calyculata & Honduras & UNAM & ITS & Linares_3386 \\
\hline cham0666 & V. chamissonis & Brazil & VATEL & ITS \& matK & CR0666 \\
\hline crib0109 & V. cribbiana & French Guyana & VATEL & ITS \& matK & CR0109 \\
\hline crib0122 & V. cribbiana & French Guyana & VATEL & $m a t \mathrm{~K}$ & CR0122 \\
\hline cribb-01 & V. cribbiana & Mexico & UNAM & ITS & Soto_7940 \\
\hline cribb-02 & V. cribbiana & Mexico & UNAM & ITS & Soto8439(nueva) \\
\hline cribb-03 & V. cribbiana & Mexico & UNAM & ITS & Soto_8370 \\
\hline dres-01 & V. dressleri & Costa Rica & UNAM & ITS & ByrdIA6(azul) \\
\hline dres-02 & V. dressleri & Costa Rica & UNAM & ITS & Byrd_IIC3 \\
\hline dres-03 & V. dressleri & Costa Rica & UNAM & ITS & Byrd_ID3 \\
\hline dres-04 & V. dressleri & Costa Rica & UNAM & ITS & Byrd_IIC2 \\
\hline hart-01 & V. hartii & Costa Rica & UNAM & ITS & Byrd_IIF1 \\
\hline hart-03 & V. hartii & $?$ & UNAM & ITS & MAS7956 \\
\hline hart-04 & V. hartii & Costa Rica & UNAM & ITS & Salas_1 \\
\hline hell-0 & V. helleri & Mexico & UNAM & ITS & Soto 8818 \\
\hline hell-01 & V. helleri & Costa Rica & UNAM & ITS & Byrd_IID5 \\
\hline hell-02 & V. helleri & Costa Rica & UNAM & ITS & Byrd_IIF4 \\
\hline insi-02 & V. insignis & Mexico & UNAM & ITS & Soto_7668 \\
\hline insi-03 & V. insignis & Honduras & UNAM & ITS & Linares 7 \\
\hline insi-04 & V. insignis & Guatemala & UNAM & ITS & Soto_8611 \\
\hline insi2507 & $V$. cf. insignis & Mexico & ITT & $\operatorname{mat} \mathrm{K}$ & muestra-13 \\
\hline insi2519 & $V$. cf. insignis & Mexico & ITT & ITS & muestra-25 \\
\hline insi2520 & $V$. cf. insignis & Mexico & ITT & ITS & muestra-26 \\
\hline insi2521 & $V$. cf. insignis & Mexico & ITT & ITS \& matK & muestra-27 \\
\hline insi2542 & $V$. cf. insignis & Mexico & ITT & ITS \& matK & muestra-20 \\
\hline insi2545 & $V$. cf. insignis & Mexico & ITT & ITS & muestra-23 \\
\hline insi2583 & V. insignis & Mexico & ITT & ITS & muestra-33 \\
\hline insi2584 & $V$. cf. insignis & Mexico & ITT & ITS & muestra-34 \\
\hline insi2594 & $V$. cf. insignis & Mexico & BUAP & ITS & $\# 005$ \\
\hline insi2618 & V. insignis & Mexico & BUAP & $m a t \mathrm{~K}$ & CR2618 \\
\hline insi2672 & V. insignis & Guatemala & Orquideario_Archila & ITS & VG-002 \\
\hline insig2548 & $V$. cf. insignis & Mexico & ITT & $\operatorname{mat} \mathrm{K}$ & muestra-26 \\
\hline lind0682 & V. lindmaniana & French Guyana & VATEL & ITS \& matK & CR0682 \\
\hline odor-01 & V. odorata & $?$ & UNAM & ITS & Soto_8822 \\
\hline odor0116 & V. odorata & French Guyana & VATEL & ITS \& matK & CR0116 \\
\hline odor0117 & V. odorata & French Guyana & VATEL & $m a t \mathrm{~K}$ & CR0117 \\
\hline
\end{tabular}


AZOFEIFA-BOLAÑOS J.B. et. al., A new species of Vanilla

\begin{tabular}{|c|c|c|c|c|c|}
\hline Code & Species & $\begin{array}{c}\text { Country of } \\
\text { origin }\end{array}$ & Depository & Locus & $\begin{array}{c}\text { Code in collection / } \\
\text { voucher }\end{array}$ \\
\hline odor-02 & V. odorata & $?$ & UNAM & ITS & Soto_8797 \\
\hline odor-04 & V. odorata & $?$ & UNAM & ITS & Soto_8365 \\
\hline odor-05 & V. odorata & $?$ & UNAM & ITS & Soto_8356 \\
\hline odor-06 & V. odorata & $?$ & UNAM & ITS & Soto_7955 \\
\hline odor2154 & V. odorata & Mexico & CITRO & ITS & V. odorata \\
\hline odor2671 & $V \cdot$ planifolia & Guatemala & OrquidearioArchila & ITS & VG-001 \\
\hline odor686 & V. odorata & $?$ & VATEL & mat $\mathrm{K}$ & CR0686 \\
\hline odor-sn & V. odorata & Surinam & UNAM & ITS & Hagsater11881 \\
\hline phae-01 & V. phaeantha & Mexico & UNAM & ITS & Carnevali_4825 \\
\hline phae-02 & $V \cdot$ phaeantha & $?$ & UNAM & ITS & Kew \\
\hline phae-03 & $V \cdot$ phaeantha & Panama & UNAM & ITS & Soto_9920 \\
\hline phae1522 & V. phaeantha & Madagascar & VATEL & $\operatorname{mat} \mathrm{K}$ & CR1522 \\
\hline phae1524 & V. phaeantha & Madagascar & VATEL & mat $\mathrm{K}$ & CR1524 \\
\hline phae1525 & V. phaeantha & Madagascar & VATEL & $\operatorname{mat} \mathrm{K}$ & CR1525 \\
\hline phae1526 & V. phaeantha & Madagascar & VATEL & matK & CR1526 \\
\hline pla2506 & $V \cdot$ planifolia & Mexico & ITT & matK & CR2506 \\
\hline plan_KJ566306 & $V \cdot$ planifolia & $?$ & Genbank & $\operatorname{mat} \mathrm{K}$ & KJ566306 \\
\hline plan0001 & $V \cdot$ planifolia & La Réunion & VATEL & ITS \& matK & CR0001 \\
\hline plan0020 & V.planifolia & La Réunion & VATEL & ITS \& matK & CR0020 \\
\hline plan0024 & V. planifolia & La Réunion & VATEL & ITS \& matK & CR0024 \\
\hline plan0027 & $V \cdot$ planifolia & La Réunion & VATEL & ITS & CR0027 \\
\hline plan0038 & $V \cdot$ planifolia & La Réunion & VATEL & ITS \& matK & CR0038 \\
\hline plan0043 & $V \cdot$ planifolia & La Réunion & VATEL & ITS & CR0043 \\
\hline plan0196 & V. planifolia & La Réunion & VATEL & ITS \& matK & CR0196 \\
\hline plan-02 & $V$. cf. planifolia & Costa Rica & UNAM & ITS & Byrd_IIA1 \\
\hline plan-03 & $V$. cf. planifolia & Honduras & UNAM & ITS & Linares8BF \\
\hline plan-05 & $V \cdot$ planifolia & Mexico & UNAM & ITS & Soto8355(nueva) \\
\hline plan-06 & $V$. planifolia & Costa Rica & UNAM & ITS & Pupulin_1966 \\
\hline plan0628 & V. planifolia & La Réunion & VATEL & ITS & CR0628 \\
\hline plan-08 & $V \cdot$ planifolia & Mexico & UNAM & ITS & MAS_8526 \\
\hline plan0802 & V. planifolia & La Réunion & VATEL & ITS \& matK & CR0802 \\
\hline plan0831 & V.planifolia & Mayotte & VATEL & ITS & CR0831 \\
\hline plan0836 & V. planifolia & Mayotte & VATEL & ITS & CR0836 \\
\hline plan 0852 & $V \cdot$ planifolia & Comores & VATEL & ITS & CR0852 \\
\hline plan0862 & V. planifolia & Comores & VATEL & ITS & CR0862 \\
\hline plan0876 & $V \cdot$ planifolia & Comores & VATEL & ITS & CR0876 \\
\hline plan0883 & $V \cdot$ planifolia & Comores & VATEL & ITS & CR0883 \\
\hline plan-14 & V. planifolia & $?$ & UNAM & ITS & KewPWC \\
\hline plan1563 & V. planifolia & Madagascar & VATEL & ITS & CR1563 \\
\hline plan 1570 & V. planifolia & Madagascar & VATEL & ITS & CR1570 \\
\hline plan-18 & $V \cdot$ planifolia & Mexico & UNAM & ITS & Soto 8808 \\
\hline plan-22 & $V \cdot$ planifolia & $?$ & UNAM & ITS & clon1324 \\
\hline plan2497 & $V \cdot$ planifolia & Mexico & ITT & matK & muestra-03 \\
\hline plan2499 & $V$. cf. planifolia & Mexico & ITT & matK & muestra-05 \\
\hline
\end{tabular}




\begin{tabular}{|c|c|c|c|c|c|}
\hline Code & Species & $\begin{array}{c}\text { Country of } \\
\text { origin }\end{array}$ & Depository & Locus & $\begin{array}{c}\text { Code in collection / } \\
\text { voucher }\end{array}$ \\
\hline plan2500 & $V$. cf. planifolia & Mexico & ITT & matK & muestra-06 \\
\hline plan2518 & $V \cdot$ planifolia & Mexico & ITT & ITS \& matK & muestra-24 \\
\hline plan2523 & V. planifolia & Mexico & ITT & ITS & muestra-29 \\
\hline plan2530 & $V \cdot$ planifolia & Mexico & ITT & ITS & muestra-01 \\
\hline plan2531 & $V \cdot$ planifolia & Mexico & ITT & ITS & muestra-02 \\
\hline plan2533 & V. planifolia & Mexico & ITT & ITS \& matK & muestra-09 \\
\hline plan2534 & V. planifolia & Mexico & ITT & ITS & muestra-10 \\
\hline plan2535 & $V \cdot$ planifolia & Mexico & ITT & ITS & muestra-11 \\
\hline plan2540 & V. planifolia & Mexico & ITT & ITS & muestra-18 \\
\hline plan2541 & V. planifolia & Mexico & ITT & ITS & muestra-19 \\
\hline plan2544 & V. planifolia & Mexico & ITT & ITS & muestra-22 \\
\hline plan2549 & V. planifolia & Mexico & ITT & ITS & muestra-28 \\
\hline plan2551 & V. planifolia & Mexico & ITT & ITS & muestra-30 \\
\hline plan2552 & V. planifolia & Costa Rica & UNA & ITS & UNA-VAN-0126 \\
\hline plan2555 & V. planifolia & Costa Rica & UNA & ITS & UNA-VAN-0198 \\
\hline plan2559 & $V \cdot$ planifolia & Costa Rica & UNA & ITS & none \\
\hline plan2582 & V. planifolia & Mexico & ITT & ITS & muestra-32 \\
\hline plan2586 & V. planifolia & Mexico & ITT & ITS & muestra-36 \\
\hline plan2587 & V. planifolia & Mexico & ITT & ITS & muestra-37 \\
\hline plan2588 & V. planifolia & Mexico & ITT & ITS \& matK & muestra-38 \\
\hline plan2589 & V.planifolia & Mexico & ITT & $\operatorname{mat} \mathrm{K}$ & muestra-39 \\
\hline plan2590 & V. planifolia & Mexico & ITT & ITS & muestra-40 \\
\hline plan2591 & V. planifolia & Mexico & ITT & ITS & muestra-41 \\
\hline plan2592 & V. planifolia & Mexico & BUAP & ITS & $\# 001$ \\
\hline plan2599 & V. planifolia & Mexico & BUAP & ITS & $\# 027$ \\
\hline plan2605 & V. planifolia & Mexico & BUAP & ITS & $\# 044$ \\
\hline plan2608 & V. planifolia & Mexico & BUAP & ITS & \#056 \\
\hline plan2616 & V. planifolia & Mexico & BUAP & ITS & $\# 081$ \\
\hline plan2625 & V. planifolia & Mexico & BUAP & ITS & $\# 111$ \\
\hline plan2632 & V. planifolia & Mexico & BUAP & ITS & $\# 128$ \\
\hline plan2645 & V. planifolia & Mexico & BUAP & ITS & $\# 180$ \\
\hline plan2650 & V. planifolia & Mexico & BUAP & ITS & \#mut \\
\hline plan2678 & V. planifolia & Guatemala & Orquideario_Archila & ITS & VG-008 \\
\hline plan2679 & V. planifolia & Guatemala & Orquideario_Archila & ITS & VG-009 \\
\hline plan2680 & V. planifolia & Guatemala & Orquideario_Archila & ITS & VG-010 \\
\hline plan2681 & V. planifolia & Guatemala & Orquideario_Archila & ITS & VG-011 \\
\hline plan2682 & V. planifolia & Guatemala & Orquideario_Archila & ITS & VG-012 \\
\hline pomp0018 & $V \cdot$ pompona & French Polynesia & VATEL & matK & CR0018 \\
\hline pomp0052 & $V \cdot$ pompona & La Réunion & VATEL & $\operatorname{mat} \mathrm{K}$ & CR0052 \\
\hline pomp0064 & $V \cdot$ pompona & $?$ & VATEL & $\operatorname{mat} \mathrm{K}$ & CR0064 \\
\hline pomp0070 & $V$. pompona & Brazil & VATEL & mat $\mathrm{K}$ & CR0070 \\
\hline pomp0079 & V. pompona & Guadelupe & VATEL & $\operatorname{mat} \mathrm{K}$ & CR0079 \\
\hline pomp0096 & $V \cdot$ pompona & French Guyana & VATEL & matK & CR0096 \\
\hline pomp-02 & $V$. pompona & $?$ & UNAM & ITS & Soto_7632 \\
\hline
\end{tabular}


AZOFEIFA-BOLAÑOS J.B. et. al., A new species of Vanilla

\begin{tabular}{|c|c|c|c|c|c|}
\hline Code & Species & $\begin{array}{c}\text { Country of } \\
\text { origin }\end{array}$ & Depository & Locus & $\begin{array}{c}\text { Code in collection / } \\
\text { voucher }\end{array}$ \\
\hline pomp0691 & $V$. pompona & $?$ & VATEL & $\operatorname{mat} \mathrm{K}$ & CR0691 \\
\hline pomp1529 & $V$. cf. pompona & Madagascar & VATEL & matK & CR1529 \\
\hline pomp1923 & $V \cdot$ pompona & Mexico & VATEL & $\operatorname{mat} \mathrm{K}$ & CR1923 \\
\hline pomp2581 & $V \cdot$ pompona & Mexico & VATEL & ITS & CR2581 \\
\hline sp.0068 & $V . \mathrm{sp}$. & Costa Rica & VATEL & ITS \& matK & CR0068 \\
\hline sp. 2180 & $V$. sp. & Costa Rica & VATEL & ITS \& matK & CR2180 \\
\hline $\mathrm{sp} .2543$ & $V$. cf. planifolia & Mexico & ITT & ITS & muestra-21 \\
\hline sp.2552 & $V$. sp. & Costa Rica & VATEL & $\operatorname{mat} \mathrm{K}$ & CR2552 \\
\hline sp. 2553 & $V$. sp. & Costa Rica & UNA & ITS \& matK & UNA-VAN-0002 \\
\hline sp. 2554 & $V$. sp. & Costa Rica & UNA & ITS \& matK & UNA-VAN-0047 \\
\hline sp.2557 & $V . \mathrm{sp}$. & Costa Rica & UNA & ITS \& matK & UNA-VAN-0002 \\
\hline sp.2719 & $V . \mathrm{sp}$. & Costa Rica & VATEL & ITS \& matK & CR2719 \\
\hline sp. 2720 & $V$ sp. & Costa Rica & VATEL & ITS & CR2720 \\
\hline sp.2721 & $V$. sp. & Costa Rica & VATEL & ITS & CR2721 \\
\hline sp.2722 & $V . \mathrm{sp}$. & Costa Rica & VATEL & ITS \& matK & CR2722 \\
\hline sp.UNA022 & $V$. sp. & Costa Rica & UNA & ITS & UNA-VAN-0022 \\
\hline sp.UNA049 & $V$. sp. & Costa Rica & UNA & ITS & UNA-VAN-0049 \\
\hline sp.UNA059 & $V$. sp. & Costa Rica & UNA & ITS & UNA-VAN-0059 \\
\hline sp.UNA228 & $V$. sp. & Costa Rica & UNA & ITS & UNA-VAN-0228 \\
\hline sp.UNA229 & $V . \mathrm{sp}$. & Costa Rica & UNA & ITS & UNA-VAN-0229 \\
\hline sp.UNA230 & $V$. sp. & Costa Rica & UNA & ITS & UNA-VAN-0230 \\
\hline xtah0017 & $V . \times$ tahitensis & French Polynesia & VATEL & ITS \& matK & CR0017 \\
\hline$x \operatorname{tah} 0163$ & V. $\times$ tahitensis & French polynesia & VATEL & matK & CR0163 \\
\hline xtah0164 & V. $\times$ tahitensis & French Polynesia & VATEL & ITS \& matK & CR0164 \\
\hline xtahi-02 & $V . \times$ tahitensis & French Polynesia & UNAM & ITS & Colin_sn \\
\hline
\end{tabular}

\section{DNA extraction and sequencing}

Total DNA was extracted from lyophilized leaf samples using the Qiagen DNA plant minikit (Dusseldorf, Germany) according to manufacturer protocols. Quantity and quality of the DNA were estimated using a Nanodrop spectrophotometer (Wilmington, USA), and DNA extracts were adjusted to $20 \mathrm{ng} \mu \mathrm{l}^{-1}$ for polymerase chain reaction (PCR) amplification.

The Internal Transcribed Spacer (ITS) of nuclear ribosomal DNA and part of the plastid maturase $\mathrm{K}$ (matK) gene were chosen for molecular characterization because they are among the most discriminant loci for orchids (Cameron 2009; Hollingsworth et al. 2009; Xu et al. 2015) and have distinct inheritances, biparental for ITS and maternal for matK. The DNA samples were PCR amplified using GoTaq kit (Promega, USA) with the two primer pairs AB101/AB102 (Sun et al. 1994) for the ITS sequence, and matK-743F (5'-CTTCTGGAGTCTTTCTTGAGC-3')/ matK-1520R (5'-CGGATAATGTCCAAATACCAAATA-3') for matK. The $25 \mu 1$ PCR reaction mixture contained: PCR reaction buffer, $50 \mathrm{nmol} \mathrm{MgCl}_{2}, 1 \mathrm{U}$ Taq polymerase (GoTaq, Promega, USA), $5 \mathrm{nmol}$ dNTPs, $10 \mathrm{nmol}$ of each forward and reverse primer and $40 \mathrm{ng}$ of genomic DNA. Amplification reactions were performed using a 96-well GeneAmp PCR System 9700 thermocycler (Applied Biosystems, USA). The annealing temperatures for primers were $60^{\circ} \mathrm{C}$ for ITS and $56^{\circ} \mathrm{C}$ for matK. Samples from Costa Rica were also amplified using the Multiplex PCR kit (Qiagen) with the same primers, and the PCR Mix and cycling conditions defined by the provider. Amplicons were sequenced in both directions as part of the 
Bibliothèque du Vivant project (Paris, France), and by Genwiz (Takeley, UK) and Genoscreen (Lille, France). Nucleotide sequences were aligned using the ClustalW package included in Bioedit software (Hall 1999) and cleaned manually to generate consensus sequences. The data set was complemented with reference sequences obtained previously (Soto Arenas \& Dressler 2010).

\section{Identification and quantification of aromatic precursors in mature fruits}

Hand-pollinated fruits of VanL (CR0068) and three V. planifolia accessions (CR0196, CR0040 and CR0038), cultivated under shade-house in La Réunion, were harvested at 8 months after pollination, in 2013 and 2014, then freeze-dried to minimize possible enzyme degradation. The fruits were ground to a fine powder with a mortar and pestle and stored at minus $20^{\circ} \mathrm{C}$ until extraction.

Extraction of volatile compounds was performed using a protocol adapted from Palama et al. (2009) and Pérez Silva et al. (2011). Fifty milligrams of the ground material was suspended in $10 \mathrm{ml}$ of phosphate buffer $(0.1 \mathrm{M}$; pH 5). The mixture was ultra-sonicated (frequency $35 \mathrm{kHz}$; AXTOR Model CD-4820) for $10 \mathrm{~min}$ at ambient temperature. The mixture was rapidly heated to $80^{\circ} \mathrm{C}$ for $10 \mathrm{~min}$ to inactivate endogenous enzymes and, after cooling at $25^{\circ} \mathrm{C}$, was centrifuged at $5000 \mathrm{rpm}$ for $3 \mathrm{~min}$ and then filtrated on a Whatman no.1 paper (Sigma-Aldrich, USA). The filtrate was complemented with $0.4 \mathrm{ml}$ of a glycosidase rich enzyme preparation (AR2000 ${ }^{\circledR}$, Sigma-Aldrich, Mexico; $70 \mathrm{mg} \cdot \mathrm{ml}^{-1}$ in phosphate buffer mentioned above) and adjusted to a volume of $10 \mathrm{ml}$ with the $\mathrm{pH} 5$ buffer solution. The extract was vortexed and incubated for $4 \mathrm{~h}$ at $40^{\circ} \mathrm{C}$ for enzymatic hydrolysis of the glycosylated precursors. One milliliter of hydrolyzed extract was filtered at $0.45 \mu \mathrm{m}$ prior to HPLC analysis.

The samples were analyzed on an Agilent 1100 series equipped with a UV-VIS detector (G1314A), degasser (G1379A), column oven (G1316A), quaternary pump unit (G1311A) and autosampler (G1313A) controlled by OpenLAB CDS EZChrom Edition (Agilent Technologies, Inc. 2013). The column used was Zorbax Eclipse plus XDB C18 (150 mm long and $4.6 \mathrm{~mm}$ in diameter; $5 \mu \mathrm{m}$, Agilent Technologies, Mexico) and the mobile phase was a mixture of two solvents: A $\left(0.1 \mathrm{M} \mathrm{KH}_{2} \mathrm{PO}_{4}, \mathrm{pH}\right.$ 3.2) and $\mathrm{B}\left(\mathrm{MeOH}, \mathrm{HPLC}\right.$ grade). Elution was achieved at $30^{\circ} \mathrm{C}$ with a gradient of $3-7 \% \mathrm{~B}$ for 2 min $\left(0.8 \mathrm{ml} \cdot \mathrm{min}^{-1}\right), 7 \% \mathrm{~B}$ for $10 \mathrm{~min}\left(0.8 \mathrm{ml} \cdot \mathrm{min}^{-1}\right), 7 \% \mathrm{~B}$ for $11 \mathrm{~min}\left(1.5 \mathrm{ml} \cdot \mathrm{min}^{-1}\right)$, followed by isocratic elution in $19 \%$ B for $25 \mathrm{~min}\left(1.5 \mathrm{ml} \cdot \mathrm{min}^{-1}\right)$ and $19 \% \mathrm{~B}$ for $40 \mathrm{~min}\left(2.0 \mathrm{ml} \cdot \mathrm{min}^{-1}\right)$. The compounds were monitored at $230 \mathrm{~nm}$, and the injection volume was $10 \mu 1$. The compounds were quantified using the external standard technique. Solutions at concentrations ranging from 10 to $100 \mathrm{mg} \cdot \mathrm{ml}^{-1}$ in the mobile phase were injected into the HPLC system to build the calibration curve.

All chemicals used were of analytical grade. The standard compounds for HPLC analyses, i.e., vanillin, vanillic acid, $p$-hydroxybenzaldehyde, $p$-hydroxybenzoic acid, $p$-hydroxybenzyl alcohol, vanillyl alcohol, anisyl alcohol and anisic acid, were from Sigma-Aldrich (Saint Quentin Fallavier, France). Anisaldehyde was obtained from Chromadex (Irvine, CA, USA) and methanol (HPLC-grade) from J.T. Baker $^{\circledR}$ (Saint Quentin Fallavier, France). The water used was Milli-Q-purified.

For each sample, extraction and HPLC were run in duplicate.

\section{Data analysis}

All statistical analyses were performed with the R statistical software (R Core Team 2013). Multiple comparisons of means of morphological and aromatic traits were performed using the Multcomp package in R (Hothorn et al. 2008).

Phylogenetic trees were inferred using the maximum likelihood method implemented in MEGA7 (Kumar et al. 2016) after determining the best substitution model using the online version of JModelTest2 (Guindon et al. 2003; Darriba et al. 2012). Branch robustness was assessed by bootstrapping 1000 datasets and branches with less than $65 \%$ bootstrap support were collapsed. 


\section{Results}

\section{Field observations}

A total of 131 vanilla plants were collected in the survey carried out throughout Costa Rica in the time period 2013-2016. Among them, 17 were tentatively classified as V. planifolia (12) or VanL (5) according to the morphology of the leaves, stem or flower. The geographic origin and code numbers of these plants are provided in Fig. 1 and Table 2.

Morphologically, the VanL plants showed most similarity with V.planifolia and $V$. $\times$ tahitensis, a species having a hybrid origin involving V. planifolia and V. odorata (Lubinsky et al. 2008). However, compared to these two species VanL plants had much smaller leaves, flowers and fruits (Fig. 2) and a distinct shape of leaves; elliptic-obovate in the case of VanL, oblong for $V$. planifolia and lanceolate for $V$. $\times$ tahitensis. On the other hand, VanL plants differed markedly from the 12 other species of the V. planifolia group (namely V. appendiculata Rolfe (Rolfe 1895), V. bahiana Hoehne (Hoehne 1950), V. cristagalli Hoehne (Hoehne 1944), V. dubia Hoehne (Hoehne 1944), V. dungsii Pabst (Pabst 1975), V. fimbriata Rolfe (Rolfe 1899), V. helleri, V. insignis Ames (Ames 1934), V. odorata, V. phaeantha Rchb.f. (Reichenbach

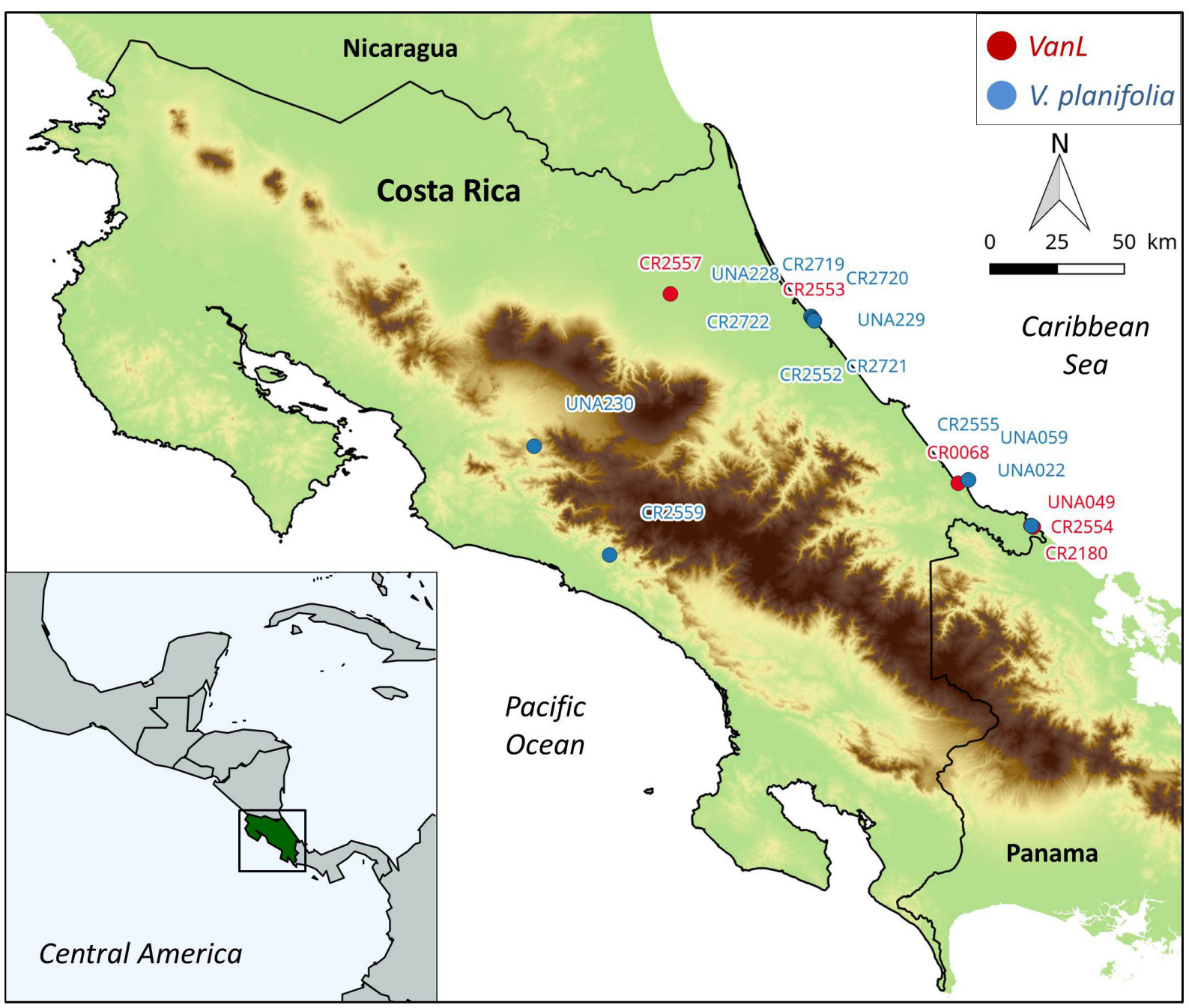

Fig. 1. Localization of Vanilla sotoarenasii M.Pignal, Azofeifa-Bolaños \& Grisoni sp. nov. (VanL) and V. planifolia Jacks. ex Andrews samples collected in Costa Rica. 


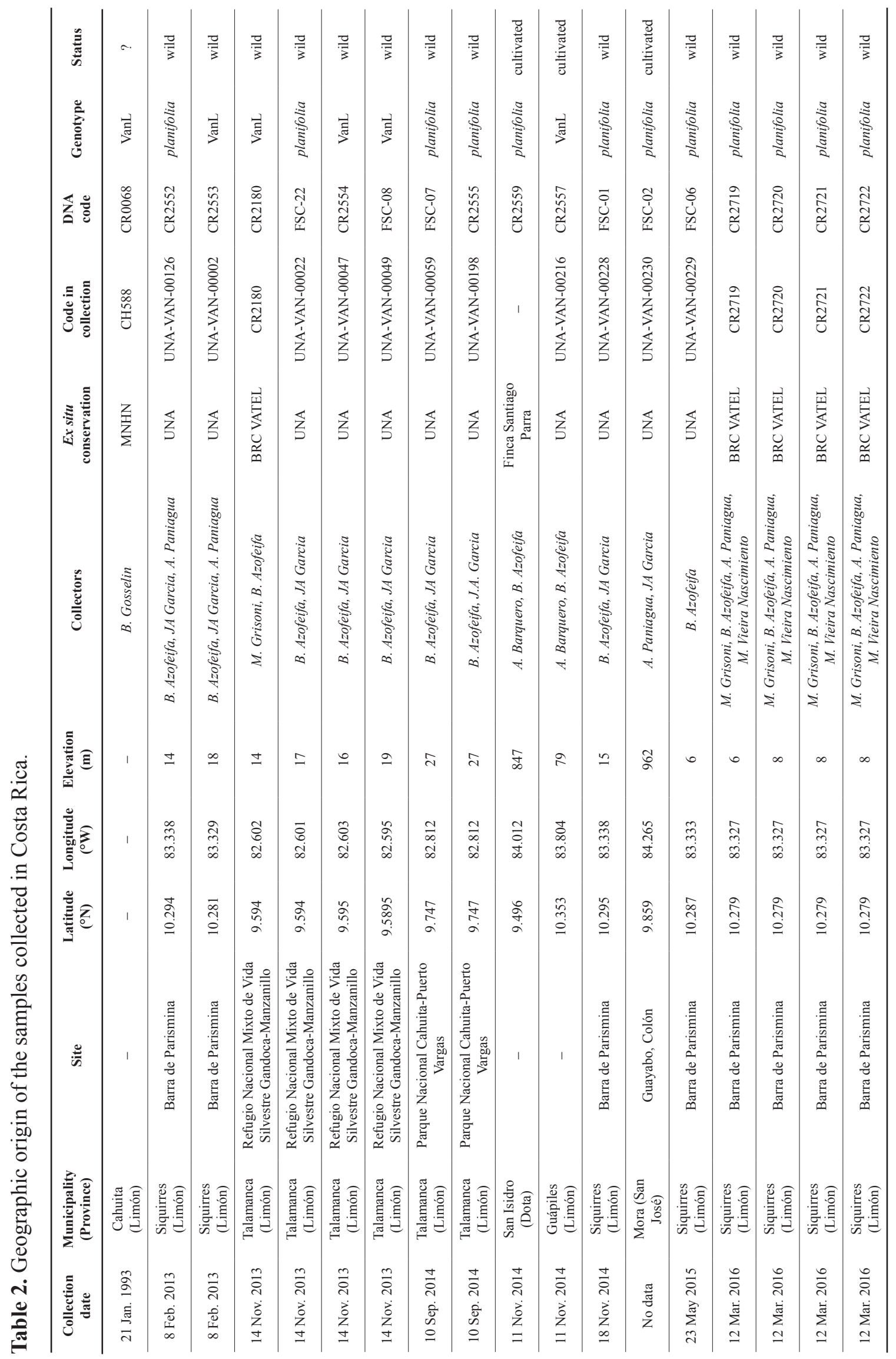


1865), V. ribeiroi Hoehne (Hoehne 1910) and V. schwackeana Hoehne (Hoehne 1944)) by color of sepal, color of petal, size and shape of tube, label ornamentation, and shape, thickness and texture of leaves.

Five out of the six VanL samples, CR0068, CR2180, CR2553, CR2554 and UNA-049, were collected in natural forests at three localities of the Caribbean province of Limón (Costa Rica), indicated in Table 2. The sixth VanL accession (CR2557) was cultivated in a farm with no information on its origin. During the survey, ten $V$. planifolia plants were found growing wild at two localities of the Limón province. Five of these accessions were collected in Barra Parismina, a human settlement established about 50 years ago that is still not connected by road to the rest of the country and where, according to one of the first settlers, vanilla was present prior to human occupation and no vanilla was ever introduced by man (Gabriel Taylor, Parismina, Costa Rica, pers. comm.). They are therefore considered to be occurring
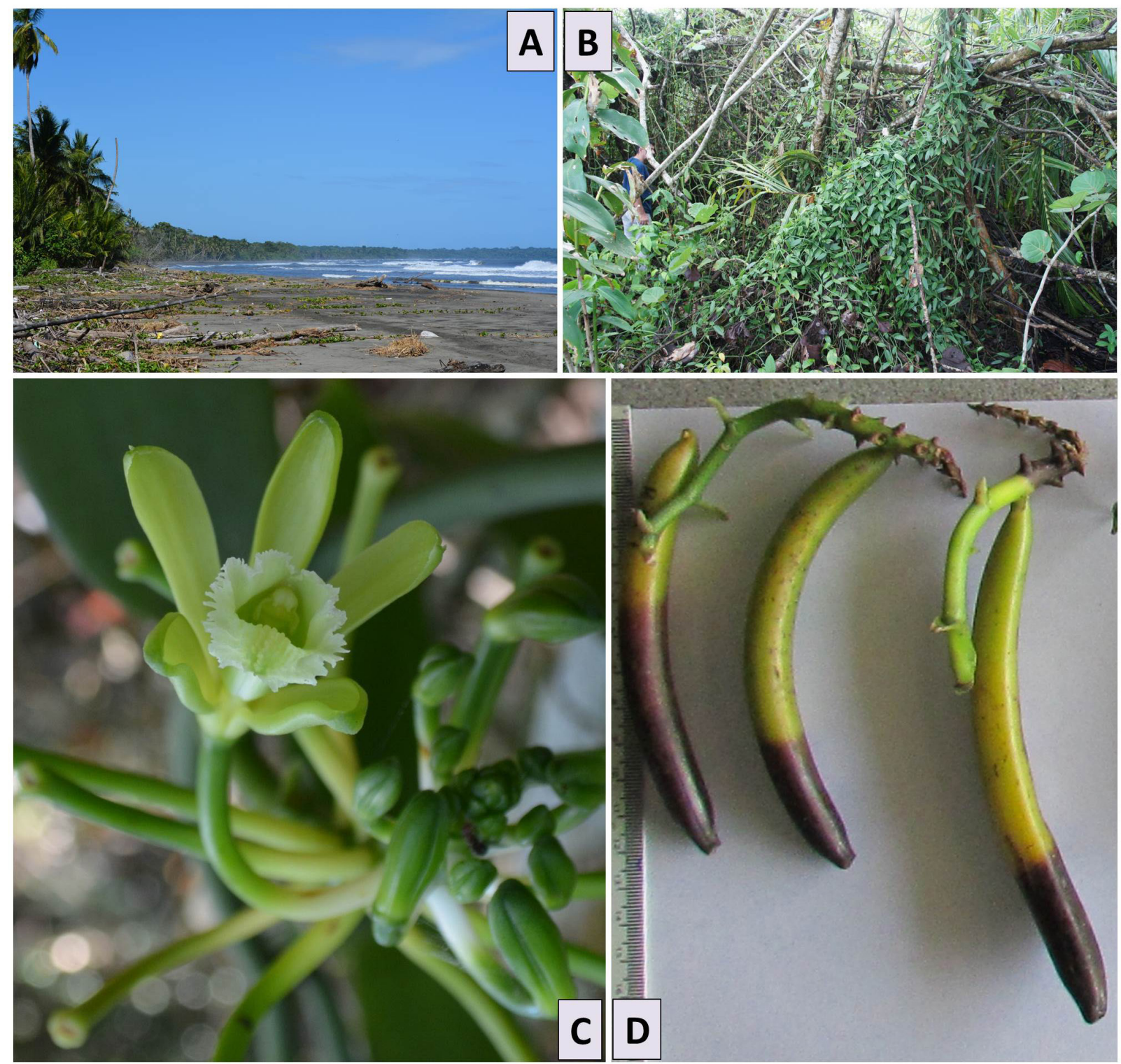

Fig. 2. Natural biotope of Vanilla sotoarenasii M.Pignal, Azofeifa-Bolaños \& Grisoni sp. nov. (VanL) at Refugio Nacional Mixto de Vida Silvestre, Gandonca Manzanillo, Costa Rica. A. View of the littoral region of Limón Province harboring VanL populations. B. Important development of VanL in the humid littoral forests of Limón. C. Flower of VanL. D. Naturally pollinated fruits of VanL at maturity. 
naturally in this area and not having escaped from local cultivation. They were morphologically indistinguishable from cultivated V. planifolia collected at farms in San Isidro (CR2559) and Mora (UNA-0230) or the three V. planifolia from Talamanca (UNA-0022, UNA-0059, CR2555).

To date, the wild populations of VanL and V. planifolia were both sampled in tropical humid forests of the southern coastal lowlands of Limón Province (Fig. 3). This biotope is characterized by plant species adapted to sandy soils such as Terminalia catappa L. (Combretaceae), Coccoloba uvifera (L.) L. (Polygonaceae), Cocos nucifera L. (Arecaceae), Costus spicatus (Jacq.) Sw. (Costaceae), Hibiscus pernambucensis Arruda (Malvaceae), Acrostichum aureum L. (Pteridaceae), Chrysobalanus icaco L. (Chrysobalanaceae), Amphitecna latifolia (Mill.) A.H.Gentry (Bignoniaceae), Rhizophora mangle L. (Rhizophoraceae) and Pterocarpus officinalis Jacq. (Fabaceae).

The VanL plant from Guápiles (CR2557) was sampled in a vanilla plot where vanilla was associated with pepper and cinnamon.
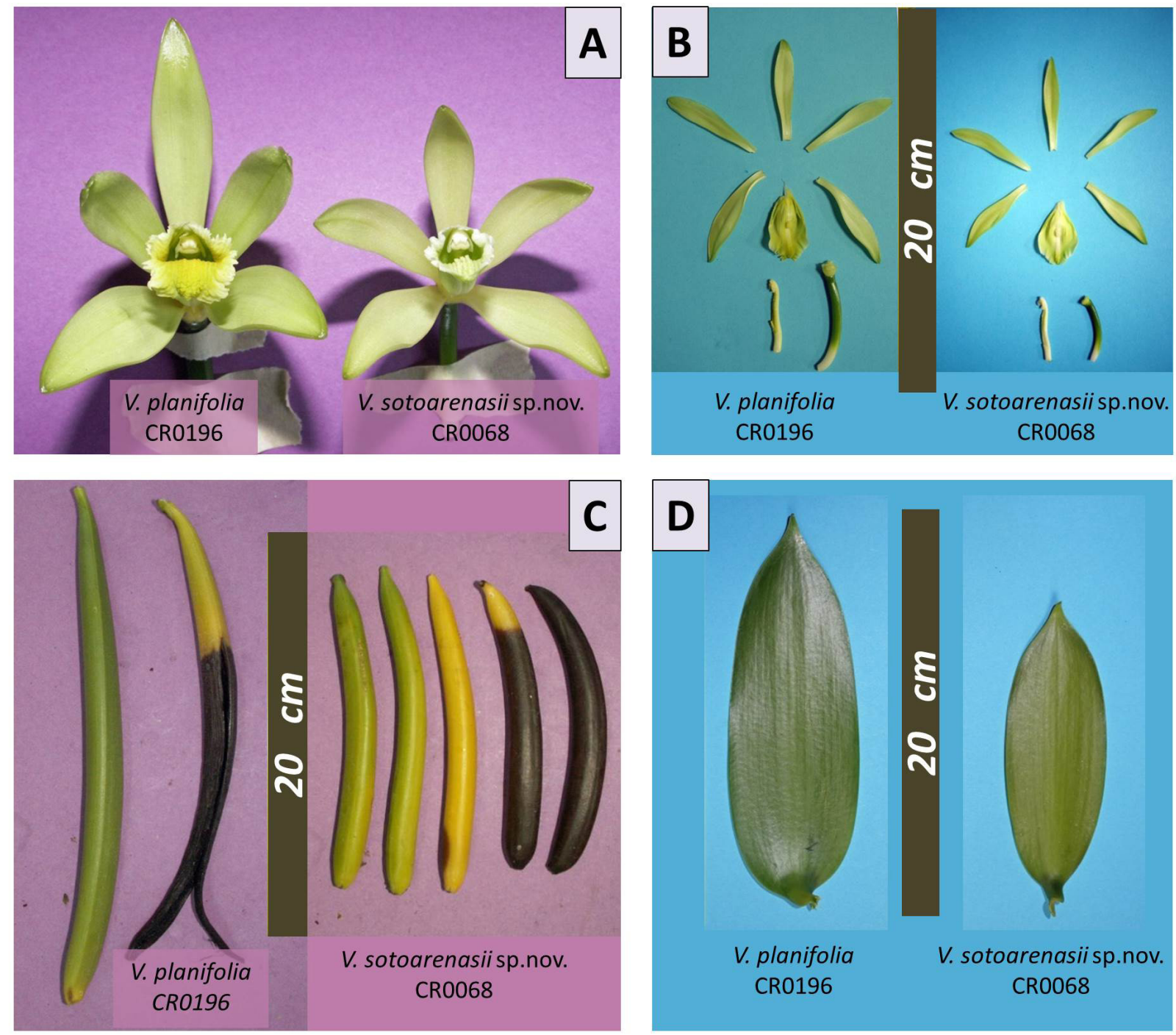

Fig. 3. Comparison of morphological traits between Vanilla sotoarenasii M.Pignal, Azofeifa-Bolaños \& Grisoni sp. nov. (accession CR0068) and V. planifolia Jacks. ex Andrews (CR0196) cultivated under shade house in La Réunion. A. Front view of entire flowers. B. Separated flower parts. C. Mature fruits. D. Leaves. 
In Gandoca-Manzanillo, Parismina and Cahuita the flowering happened from October to January, as deduced from the many racemes found in mid-November bearing flowers and young fruits. Mature vanilla beans were harvested in December 2015 from the VanL population of Guápiles (CR2557), which indicated a flowering time probably ending in March.

\section{Phylogenetic analysis}

To elucidate the taxonomic position of VanL plants, the nuclear ITS DNA and the matK plastid gene were sequenced for 125 and 55 vanilla accessions, respectively. The sample set included VanL specimens, accession representatives of the diversity of the $V$. planifolia group, as well as outgroup species (Table 1).

The phylogenetic tree inferred from the 506 positions of the 125 aligned ITS sequences (465 to $500 \mathrm{nt}$ ) revealed a clade separated with $93 \%$ bootstrap support, containing the five VanL accessions (CR2180, CR2553, CR2554, CR2557 and UNA049) along with CR0068 from BRC Vatel and two accessions from the AMO, collected in Costa Rica and Honduras respectively, identified as V. planifolia cf. plan-02 and plan-03 (Fig. 4). This clade was within the $V$. planifolia accessions and close to the $V$. bahiana/ $V$. phaeantha clade. It was more distantly related to the $V$. insignis and the $V$. helleri$V$. odorata $-V \times$ tahitensis clades.

The eight partial ITS sequences in the VanL clade differed from all the accessions of the $V$. planifolia clade by two conserved nucleotides at positions 390 and 479 of the alignment (Table 3). Similarly, $V$. bahiana differed from $V$. phaeantha by only two conserved nucleotides (nt 172 and 420). In contrast, the $V$. planifolia clade differed from the $V$. bahiana and $V$. phaeantha group by 13 conserved nucleotides, and from $V$. insignis by 15 conserved nucleotides.

The phylogenetic tree inferred from the 741 positions of the 55 aligned matK sequences (699 to 734 nt) separated $V$. planifolia with high bootstrap support from its most closely related species, including $V$. odorata, $V$. insignis, $V$. bahiana and $V$. phaeantha (Fig. 5). The eight VanL accessions sequenced fell within the $V$. planifolia clade, confirming their very close relationship with this species.

Phylogenetic trees inferred using the Neighbor Joining, Parsimony and Bayesian methods were congruent with the ML trees (data not shown).

\section{Morphology of vegetative and reproductive organs of VanL}

The morphology of the leaf, stem, and flower of VanL is very similar to that of V. planifolia (Fig. 2). However, the former differs from the latter by a highly significant reduction in size of the vegetative and reproductive organs (Table 4). In average, leaf and stem dimensions are 29 to $41 \%$ smaller in VanL compared to V. planifolia.

The size reduction in VanL is less important in the flower, with tube length only 7\% and sepal length $12 \%$ lesser than for $V$. planifolia. However, in VanL, the dorsal sepal is $29 \%$ narrower and the ovary $19 \%$ shorter than in $V$. planifolia. The blooming period of VanL cultivated in La Réunion was approximately two weeks earlier than that of $V$. planifolia accessions, but they overlapped from October to November.

Mature fruits of VanL were $45 \%$ shorter and $55 \%$ lighter than those of $V$. planifolia (Fig. 2; Table 4). They were also indehiscent and more cylindrical, contrary to most $V$. planifolia fruits, which dehisce at maturity and have a more triangular section. 
Fig. 4. Phylogenetic tree derived from the partial ITS sequences (506 positions) of the 125 accessions listed in Table 1, showing the differentiation of the Vanilla sotoarenasii M.Pignal, Azofeifa-Bolaños \& Grisoni sp. nov. clade from $V$. planifolia Jacks. ex Andrews and all other related species. The tree was inferred using the Maximum Likelihood method based on the Tamura-Nei model with invariant sites and Gamma distribution of evolutionary rates. The figures indicate the percentage of bootstrap support. Branches with less than $65 \%$ support were collapsed. Countries of origin: $\mathrm{Bra}=\mathrm{Brazil} ; \mathrm{Com}=$ Comoros: $\mathrm{CR}=$ Costa Rica; $\mathrm{FGu}=$ French Guiana; FPo = French Polynesia; Gua = Guatemala; Hon $=$ Honduras; Mad = Madagascar; May $=$ Mayotte; Mex = Mexico; Run = La Réunion; na = geographic origin not available. Numbers in brackets indicate the number of similar accessions merged in one branch for outgroup species.

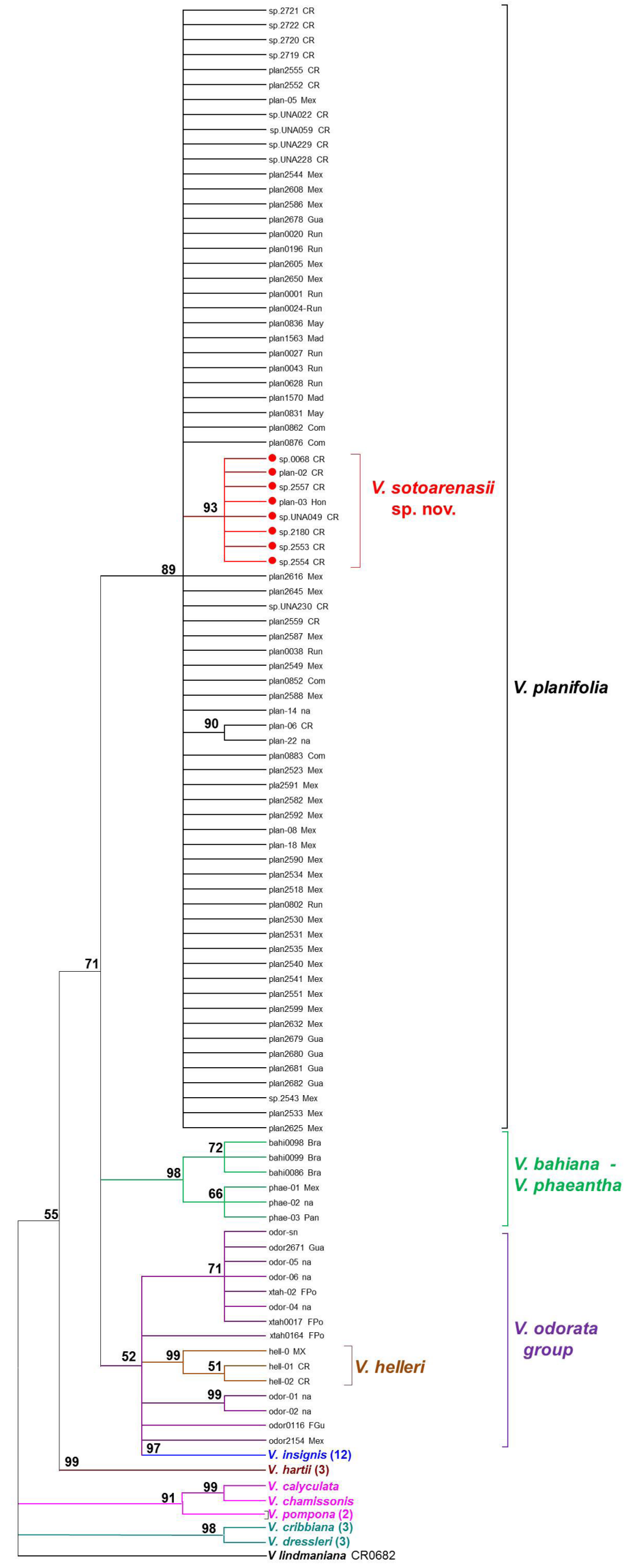


Table 3. Inter-clade polymorphisms of within-clade-conserved nucleotides along the partial ITS sequence of Vanilla planifolia Jacks. ex Andrews, $V$. sotoarenasii M.Pignal, Azofeifa-Bolaños \& Grisoni sp. nov. and their most closely related species. The triangular matrix on the right indicates the number of polymorphic sites between species. Nucleotides diverging from the $V$. planifolia sequence are in bold. $\mathrm{Y}=\mathrm{C}$ or $\mathrm{T}, \mathrm{K}=\mathrm{G}$ or $\mathrm{T}$.

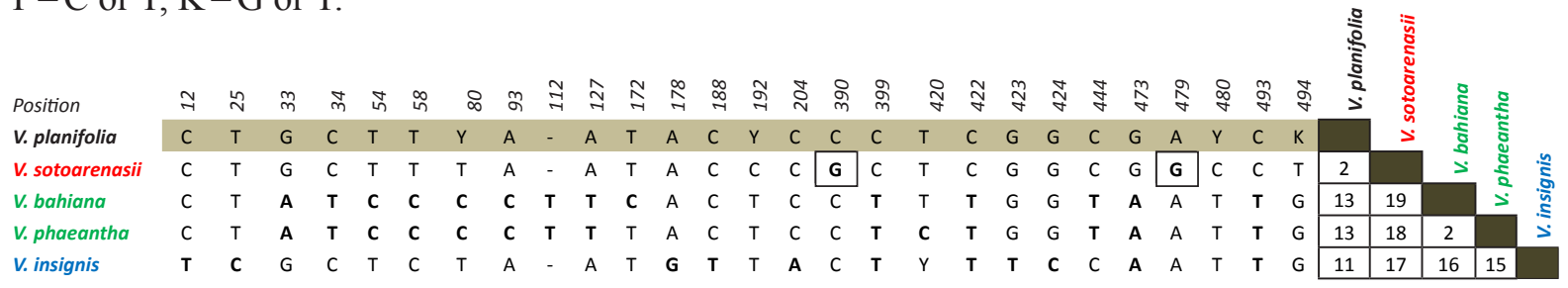

Table 4. Means of different measurements on vegetative and reproductive organs of two accessions of Vanilla sotoarenasii M.Pignal, Azofeifa-Bolaños \& Grisoni sp. nov. (CR0068 and CR2180) and two accessions of $V$. planifolia Jacks. ex Andrews (CR0040 and CR0196). Measurements are in mm unless otherwise indicated. In each line, means with different letters are significantly different $(p<0.005$, Tukey's test). StE $=$ standard error.

\begin{tabular}{|c|c|c|c|c|c|c|c|c|c|c|c|c|}
\hline \multirow[b]{3}{*}{ Characters } & \multicolumn{6}{|c|}{ V. sotoarenasii sp. nov. } & \multicolumn{6}{|c|}{ V.planifolia } \\
\hline & \multicolumn{3}{|c|}{ CR0068 } & \multicolumn{3}{|c|}{ CR2180 } & \multicolumn{3}{|c|}{ CR0040 } & \multicolumn{3}{|c|}{ CR0196 } \\
\hline & mean & StE & & mean & StE & & mean & StE & & mean & StE & \\
\hline length of leaf & 76.0 & 2.28 & $a$ & 105.8 & 3.85 & $b$ & 149.4 & 2.58 & $c$ & 146.5 & 3.65 & $c$ \\
\hline width of leaf & 32.7 & 0.58 & $a$ & 27.4 & 1.29 & $a$ & 50.0 & 0.96 & $b$ & 47.9 & 1.08 & $b$ \\
\hline diameter of stem & 5.8 & 0.09 & $a$ & 6.1 & 0.12 & $a$ & 10.3 & 0.25 & $b$ & 9.9 & 0.26 & $b$ \\
\hline length of internode & 71.4 & 3.00 & $a$ & 91.0 & 3.03 & $a$ & 117.7 & 3.65 & $b$ & 122.2 & 4.66 & $b$ \\
\hline Number of items & 30 & & & 14 & & & 24 & & & 30 & & \\
\hline length of sepal sup & 50.3 & 0.45 & $a$ & 50.6 & 0.64 & $a$ & 57.9 & 0.43 & $b$ & 56.8 & 0.53 & $b$ \\
\hline width of sepal sup & 9.5 & 0.22 & $a$ & 8.9 & 0.33 & $a$ & 13.5 & 0.29 & $b$ & 12.6 & 0.33 & $b$ \\
\hline length of tube & 42.6 & 0.32 & $a$ & 43.2 & 0.67 & $a$ & 47.0 & 0.40 & $b$ & 45.7 & 0.48 & $b$ \\
\hline width of tube & 10.8 & 0.12 & $a$ & 11.3 & 0.18 & $a$ & 13.6 & 0.19 & $b$ & 13.0 & 0.22 & $b$ \\
\hline length of ovary & 37.8 & 0.53 & $a$ & 45.9 & 0.93 & $b$ & 53.1 & 0.61 & $c$ & 49.9 & 0.72 & $c$ \\
\hline Number of items & 30 & & & 19 & & & 22 & & & 30 & & \\
\hline weight of mature fruit (g) & 6.6 & 0.17 & $a$ & - & - & & 18.1 & 0.84 & $b$ & 18.3 & 0.65 & $b$ \\
\hline length of mature fruit & 114 & 2.20 & $a$ & - & - & & 201 & 3.66 & $b$ & 203 & 2.26 & $b$ \\
\hline Number of items & 16 & & & - & & & 17 & & & 22 & & \\
\hline
\end{tabular}

\section{Aromatic content of mature fruits}

Strongly contrasted aromatic profiles were observed between VanL and V. planifolia by comparing the contents of nine volatile precursors detected in mature fruits by HPLC (Table 5). The fruits of VanL had a much lower content of vanillyl compounds, particularly vanillin which did not exceed $0.26 \%$ of dry matter, while it was over $2.28 \%$ in V. planifolia beans. Conversely, VanL fruits had significant amounts of anisyl compounds which were not detected by HPLC in $V$. planifolia fruits, and $p$-hydroxybenzyl (PHB) alcohol was present at a much higher titer in VanL compared to V. planifolia. The contents of the two other $p$-hydroxyl compounds were not significantly different between VanL and V. planifolia. 


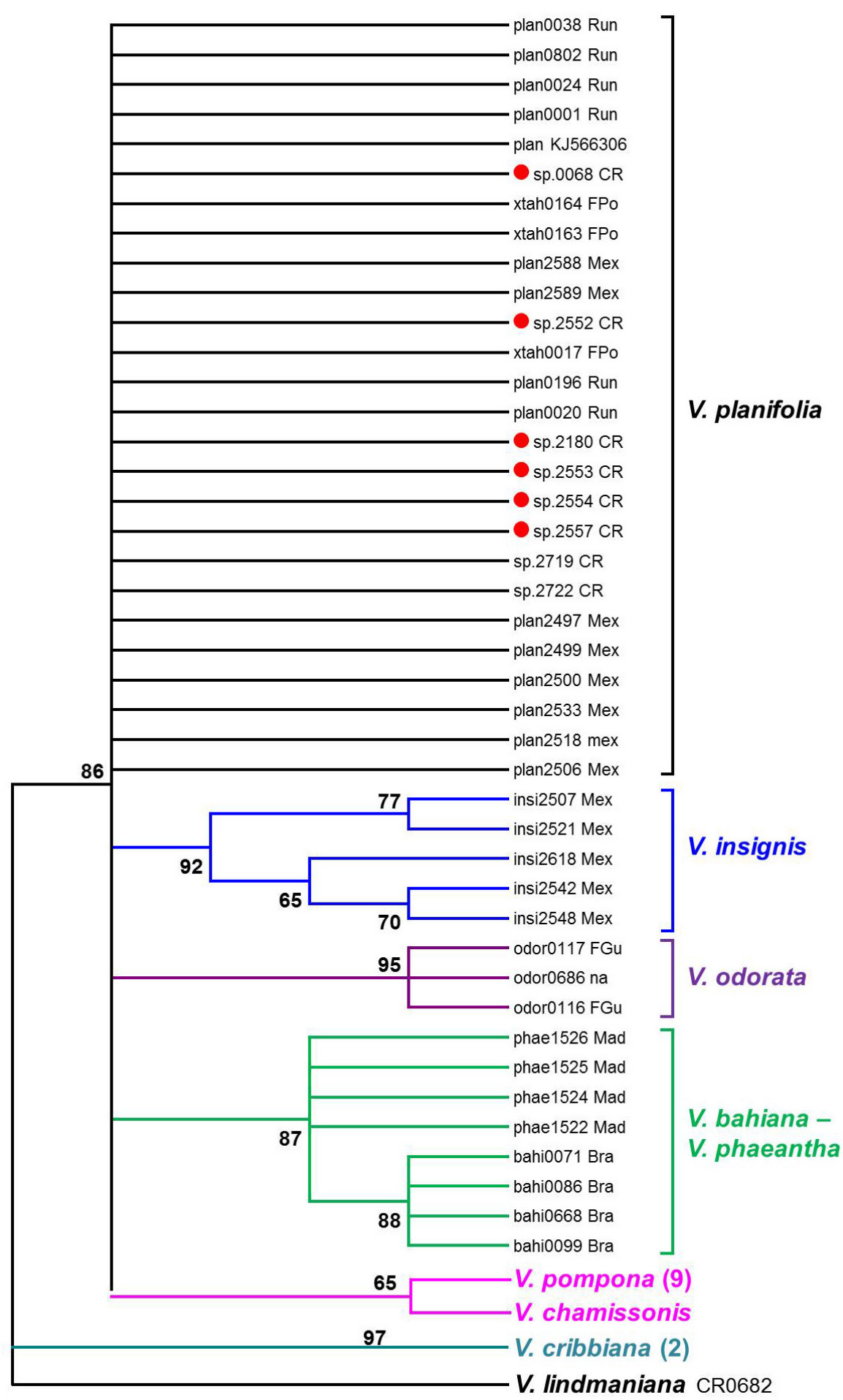

Fig. 5. Phylogenetic tree derived from the partial matK sequences ( 725 positions) of the 55 accessions listed in Table 1, showing the Vanilla sotoarenasii M.Pignal, Azofeifa-Bolaños \& Grisoni sp. nov. accessions (red dots) within the $V$. planifolia clade but distinct from other related species. The tree was inferred using the Maximum Likelihood method based on the Hasegawa-Kishino-Yano model and Gamma distribution of evolutionary rates. The figures indicate the percentage of bootstrap support. Countries of origin: $\mathrm{Bra}=$ Brazil; $\mathrm{CR}=$ Costa Rica; $\mathrm{FGu}=$ French Guiana; FPo $=$ French Polynesia; Mad = Madagascar; Mex = Mexico; Run $=$ La Réunion; na $=$ geographic origin not available . Numbers in brackets indicate the number of similar accessions merged in one branch for outgroup species. 
As a whole, the VanL fruit had a significantly lower (about 30\%) level of total aromatic content (all nine molecules) and a very distinct aromatic profile compared to $V$. planifolia. Indeed, the volatiles of V. planifolia fruits were strongly dominated by vanillyl compounds $(83.1 \%$ of all volatiles, particularly vanillin which represented 68\%). By contrast, the VanL fruits contained a more equilibrated profile with a slight dominance of vanillyl compounds ( $41.9 \%$ of all volatiles, in which vanillyl-alcohol represented $31 \%$ ), $p$-hydroxybenzyl and anisyl compounds (35.9\% and $22.2 \%$, respectively).

The above results indicate than VanL and V. planifolia are very closely related but significantly distinct in morphological and biochemical traits, as well as in nuclear nucleotide sequences. We therefore propose to place VanL in a specific taxon distinct from V. planifolia, and to name it Vanilla sotoarenasii M.Pignal, Azofeifa-Bolaños \& Grisoni sp. nov.

\section{Taxonomy}

Class Equisetopsida C.Agardh (Agardh et al. 1825)

Subclass Magnoliidae Novák ex Takht. (Takhtajan 1967)

Superorder Lilianae Takht. (Takhtajan 1967)

Order: Asparagales Link (Link 1829)

Family Orchidaceae Juss. (de Jussieu 1789)

Subfamily Vanilloideae (Lind1.) Szlach. (Szlachetko 1995)

Tribe Vanilleae (Blume 1835)

Genus Vanilla Plum. ex Mill. (Miller 1754)

Subgenus Xanata Soto Arenas \& Cribb (Soto Arenas \& Cribb 2010)

Section Xanata Soto Arenas \& Cribb (Soto Arenas \& Cribb 2010)

Vanilla sotoarenasii M.Pignal, Azofeifa-Bolaños \& Grisoni sp. nov. urn:Isid:ipni.org:names:77160155-1

Figs 2, 3, 6

\section{Diagnosis}

A Vanilla planifolia similis, sed folia caulesque breviores (folium: $7.6-10.6 \times 2.7-3.3 \mathrm{~cm}$ versus 14.7-14.9 × 4.8-5 cm), laminae breviores, ellipticae-oblongaeque, flores albiores, tubus floris, sepala petalaque breviores, sepalum dorsale angustius, labellum angustiius cum papillis salientioribus, ovarium brevitius $(3.8-4.6 \mathrm{~cm}$ versus $5-5.3 \mathrm{~cm})$, fructus brevitior $(11.4 \mathrm{~cm}$ versus $20.1-20.3 \mathrm{~cm})$ indehiscensque, sectio fructi cylindrica (versus trigona). Moleculae aromaticae fructi absimilis.

\section{Etymology}

This species is dedicated to Dr. Miguel Angel Soto Arenas (1963-2009), authority in orchid floristics and ecology, particularly in the Vanilla genus.

\section{Type material}

Holotype

COSTA RICA: Cahuita (ex hort. parc E. Liais, from plants collected by B. Gosselin in 1993), 8 Oct. 1996, Pignal 396 b (holo-: P: P00075132).

\section{Paratypes}

COSTA RICA: Limón Province: Talamanca, Refugio Nacional Mixto de Vida Silvestre GandocaManzanillo, 9.594 ${ }^{\circ} \mathrm{N}, 82.602^{\circ} \mathrm{W}$, altitude $2 \mathrm{~m}, 14$ Nov. 2013 (originally collected), cultivated in BRC Vatel, Saint Pierre, La Réunion, France CRV2180, 28 Feb. 2016, M. Grisoni \& J.B. Azofeifa-Bolaños 
Table 5. Means of volatile compounds quantified by HPLC in mature beans of $V$. sotoarenasii M.Pignal, Azofeifa-Bolaños \& Grisoni sp. nov. (CR0068; 3 samples) and V. planifolia Jacks. ex Andrews (CR0196, CR0038, CR0040; 9 samples). Contents are expressed as grams of compound per $100 \mathrm{~g}$ dry matter. $\mathrm{nd}=$ compound not detected. Averages with different letters within rows are significantly different $(p<0.05)$.

\begin{tabular}{|c|c|c|c|c|}
\hline \multirow[b]{2}{*}{ Compounds } & \multicolumn{2}{|c|}{ V. sotoarenasii sp. nov. } & \multicolumn{2}{|c|}{ V.planifolia } \\
\hline & $\mathrm{g} / 100 \mathrm{~g} \mathrm{dw}$ & $\%$ & $\mathrm{~g} / 100 \mathrm{gdw}$ & $\%$ \\
\hline Vanillin & $0.26 \mathrm{a}$ & 10.9 & $2.28 \mathrm{~b}$ & 68.0 \\
\hline Vanillic acid & nd a & 0.0 & $0.19 \mathrm{~b}$ & 5.5 \\
\hline Vanillyl alcohol & $0.73 \mathrm{a}$ & 31.0 & $0.32 \mathrm{~b}$ & 9.6 \\
\hline Total vanillyl compounds & $0.99 \mathrm{a}$ & 41.9 & $2.79 \mathrm{~b}$ & 83.1 \\
\hline$p$-hydroxybenzaldehyde & $0.20 \mathrm{a}$ & 8.5 & $0.18 \mathrm{a}$ & 5.4 \\
\hline$p$-hydroxybenzoic acid & $0.37 \mathrm{a}$ & 15.8 & $0.37 \mathrm{a}$ & 11.2 \\
\hline$p$-hydroxybenzyl alcohol & $0.27 \mathrm{a}$ & 11.6 & $0.01 \mathrm{~b}$ & 0.3 \\
\hline Total $p$-hydroxybenzyl compounds & $0.85 \mathrm{a}$ & 35.9 & $0.56 \mathrm{~b}$ & 16.9 \\
\hline Anisyl alcohol & $0.24 \mathrm{a}$ & 10.2 & nd $b$ & 0.0 \\
\hline Anisaldehyde & $0.03 \mathrm{~b}$ & 1.4 & nd $b$ & 0.0 \\
\hline Anisic acid & $0.25 \mathrm{a}$ & 10.6 & nd $b$ & 0.0 \\
\hline Total anisyl compounds & $0.52 \mathrm{a}$ & 22.2 & nd $b$ & 0.0 \\
\hline Total & $2.36 \mathrm{a}$ & 100 & $3.35 \mathrm{~b}$ & 100 \\
\hline
\end{tabular}

JJMM01 (REU: REU13363); Canton of Talamanca, Refugio de Vida Silvestre Gandoca-Manzanillo (originally collected), cultivated in INISEFOR, Heredia, Costa Rica, 14 Nov. 2013, M. Grisoni, B. Azofeifa and J. García 2180 (CR 281507), cultivated at the same locality, B. Azofeifa and J. García 0047 (CR 281508); Canton of Siquirres, Barra de Parismina (originally collected), cultivated in INISEFOR, Heredia, Costa Rica, 8 Feb. 2013, B. Azofeifa, J. García and A. Paniagua 0002 (CR 281509).

\section{Description}

Hemiepiphytic vine up to $15 \mathrm{~m}$ high. Stems flexuous, terete, smooth, green, 5-6 mm thick; internodes, sometimes slightly curved apically, ca $10 \mathrm{~cm}$ long. Terrestrial roots pubescent, ramified, ca $2 \mathrm{~mm}$ thick; both attaching and free aerial roots terete, pubescent, ca $2 \mathrm{~mm}$ thick at base, ca $3.5 \mathrm{~mm}$ at middle. Leaves regularly alternate. Blade elliptic to obovate, slightly fleshy (ca 27 veins visible on dry specimens); base rounded to cuneate, shortly pseudopetiolate; apex shortly acuminate (acumen sharp, $12 \mathrm{~mm}$ long, $5 \mathrm{~mm}$ at base), slightly recurved; margin thinned; pseudopetiole canaliculate, $16 \times 5 \mathrm{~mm}$. Inflorescence: raceme, ca 10-20-flowered, 7-13 cm, sometimes located on short axillary branches, sometimes lying on leafy stems. 3-4 inflorescence bracts, foliaceous, basal bract pseudopetiolate $(40 \times 20 \mathrm{~mm})$, upper bract sessile and shorter $(20 \times 8 \mathrm{~mm}$ and $12 \times 3 \mathrm{~mm})$. Flowers at anthesis successively, ephemeral, 1-2 simultaneously, white green, sepals forming an angle of approximately $45^{\circ}$ with axis of column, petals more or less parallel to this axis. Ovary terete, smooth, slightly arcuate, white at base and green on upper $2 / 3,30 \mathrm{~mm}$ long and $4 \mathrm{~mm}$ in diameter. Parts of perianth with whitish inclusions (visible on dry specimens), longitudinally oriented, ca $0.1-2 \mathrm{~mm}$ long, more numerous on petals, dorsal sepal narrow elliptic to oblanceolate, ca 11 -veined, $40 \times 10 \mathrm{~mm}$, apex acute, rounded, base attenuate-clawed, slightly concave, canaliculate. Lateral sepals, elliptic asymmetric, slightly falciform, ca 11-veined, 38 $\times 10.5 \mathrm{~mm}$, apex acute, slightly cupuliform, base attenuate, canaliculate, $4 \mathrm{~mm}$ wide. Petals elliptic asymmetric, slightly falciform, ca 12-veined, carinate dorsally (carena $1.2 \mathrm{~mm}$ wide), $38 \times 9 \mathrm{~mm}$, apex rounded, base attenuate, $3 \mathrm{~mm}$ wide (Fig. 6). Labellum attached to column along margins of $5 / 7$ (ca 20 
$\mathrm{mm}$ ), funnel-shaped, spread apically (opening about $10 \mathrm{~mm}$ ), trilobed, ca 30-veined ramified in distal third, margin crenulate. With 5-6 fimbriated scales, ca $1.5 \times 1.5 \mathrm{~mm}$, at about middle of labellum. Lateral lobes, obliquely triangular, ca 11 -veined, $10 \mathrm{~mm}$ high and $7 \mathrm{~mm}$ wide, margins widely undulate. Midlobe quadrate, $20 \mathrm{~mm}$ wide and $6 \mathrm{~mm}$ high, about 12-veined, converging at apex. Papillae on four central veins, on apical half. Column trigonous-semicylindrical, $28 \mathrm{~mm}$ long, $2.5 \mathrm{~mm}$ wide, apically with 2 lateral auricles, crenulate, $2.5 \mathrm{~mm}$ high and $4 \mathrm{~mm}$ wide. Rostellum quadrangular, ca $3 \times 3 \mathrm{~mm}$. Stigma bilobed. Anther articulated, connective keel-shape, $2 \times 2 \mathrm{~mm}$, bicarinate on top. Operculum helmet-shaped, $2 \times 3 \mathrm{~mm}$. Pollinarium, 2. Fruit arcuate, banana-shaped, green, turning yellowish and then brown, $11-16 \times 1.5 \mathrm{~cm}$, with cylindrical section.

\section{Phenology}

The flowering period occurs from October to March in Costa Rica.

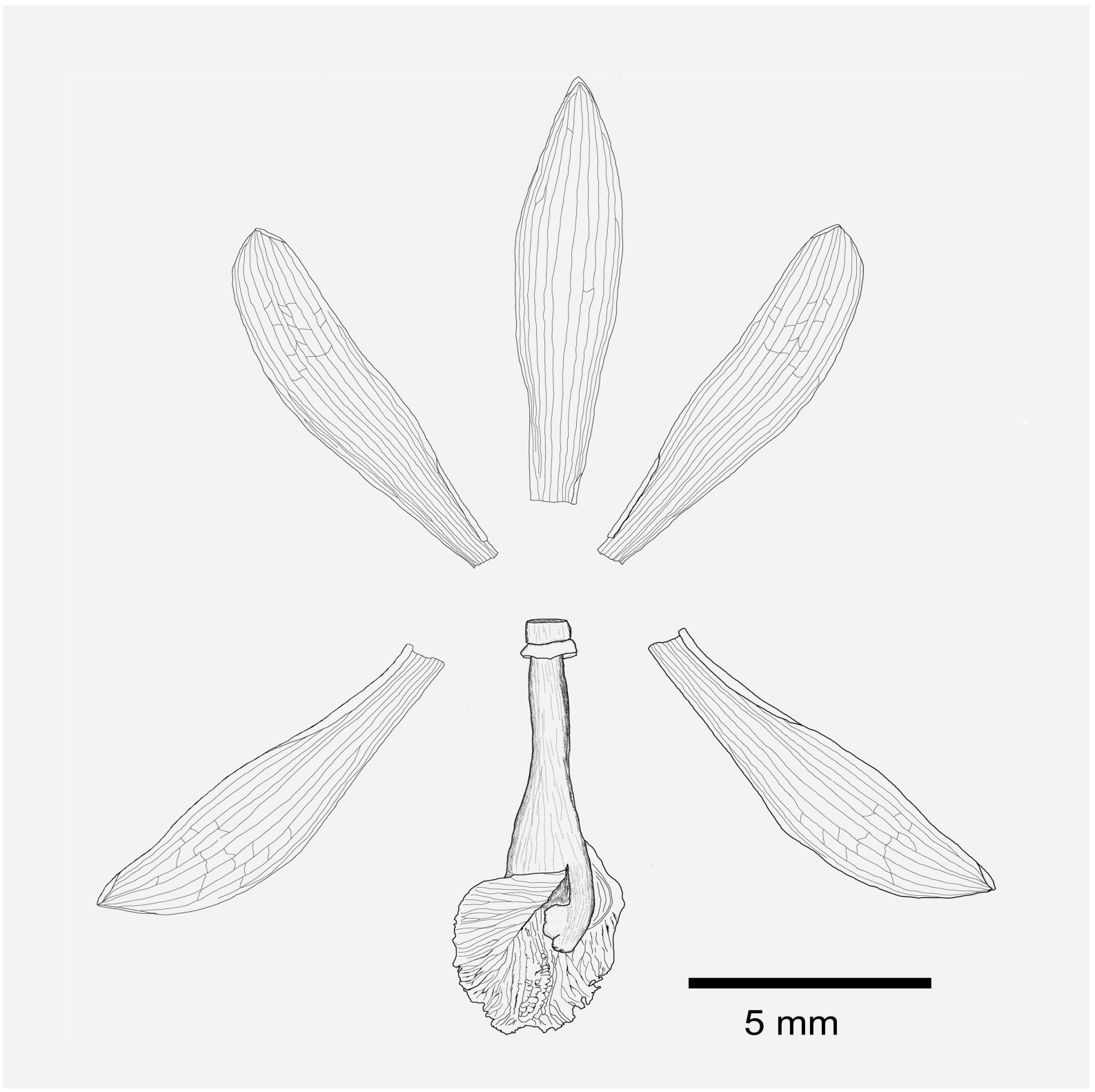

Fig. 6. Croquis drawing of a flower of Vanilla sotoarenasii M.Pignal, Azofeifa-Bolaños \& Grisoni sp. nov. 


\section{IUCN status -Vulnerable}

The populations of $V$. sotoarenasii sp. nov. observed in the province of Limón showed strong vegetative development of vines and natural seed set was frequently observed. However, a small number of populations have so far been observed and only over a very limited area of Limón Province (10 populations over a coastal strip of about $50 \mathrm{~km}^{2}$ ), and its habitat is periodically submerged by the ocean. This makes us inclined to tentatively classify $V$. sotoarenasii sp. nov. as vulnerable D2 (IUCN 2012) until further data on distribution and population dynamics have been obtained.

\section{Discussion}

Using complementary approaches involving morphology of the reproductive and vegetative systems, molecular barcoding and the accumulation of secondary metabolites in fruits, we highlighted specific traits for the vanilla populations sampled on the Caribbean coast of Costa Rica which revealed a new taxon, $V$. sotoarenasii sp. nov. The morphology of the flowers and leaves clearly assigned $V$. sotoarenasii sp. nov. within the V. planifolia group (Soto Arenas \& Dressler 2010). Based on flower morphology, $V$. sotoarenasii sp. nov. was more similar to $V$. planifolia and $V$. $\times$ tahitensis than to any other vanilla species of this group. However, $V$. sotoarenasii sp. nov. differs from the other two species by several characteristics (Table 6).

Firstly, our data and previous data by Costantin \& Bois (1915) and Portères (1953) showed that V. sotoarenasii sp. nov. has a significantly smaller size for all organs measured (stem, leaf, flower and fruit) compared to $V$. planifolia and $V$. $\times$ tahitensis, and had a distinct shape of the leaves: elliptic to obovate in the case of $V$. sotoarenasii sp. nov., elliptic to oblong for $V$. planifolia and narrowly oblong to lanceolate for $V . \times$ tahitensis (Table 6). In addition, the flowers of $V$. sotoarenasii sp. nov. are more whitish, with a narrower label showing marked papillae, compared to those of $V$. planifolia, which are more greenish, with a wider label and smooth papillae.

On the basis of HPLC quantification of hydrolyzed volatile compounds in mature fruits, the aromatic precursors of $V$. sotoarenasii sp. nov. are very distinct from those of $V$. planifolia. In particular, fruits of $V$. sotoarenasii sp. nov. were characterized by less predominant vanillin content and the presence of anisyl compounds. They should develop, after over-maturation or curing, flavors extremely different from those of $V$. planifolia and more similar to those of $V$. pompona or $V$. $\times$ tahitensis (Pérez-Silva et al. 2006; Brunschwig et al. 2009; Maruenda et al. 2013).

On the other hand, molecular analysis of nuclear DNA sequences (ITS) unambiguously separated the $V$. sotoarenasii sp. nov. group of plants from the $V$. planifolia group including 68 accessions originating from seven countries (Comoros, Costa Rica, Guatemala, Madagascar, Mayotte, Mexico, and La Réunion). This result is corroborated by amplified fragment length polymorphism (AFLP) analyses by Bory et al. (2008) that clearly separated V. sotoarenasii sp. nov. CR0068 from 303 V. planifolia genotypes of diverse origins with an average distance comparable to the distance between $V$. planifolia and $V$. $\times$ tahitensis. The facts that $\mathrm{i}$ ) at the plastid DNA level (partial matK sequence) $V$. sotoarenasii sp. nov. and $V$. planifolia share the same clade, and ii) in the ITS phylogeny $V$. sotoarenasii sp. nov. is in an internal position within the $V$. planifolia clade (like $V$. helleri within the $V$. odorata cluster), suggest the recent radiation of $V$. sotoarenasii sp. nov. from $V$. planifolia populations.

So far, $V$. sotoarenasii sp. nov. has only been observed in the Limón Province of Costa Rica where it is sympatric with $V$. planifolia, which has been reported as native to Costa Rica (Soto Arenas \& Dressler 2010). However, recent introductions in the country of $V$. planifolia cultivars and hybrids have also been documented (Soto Arenas \& Dressler 2010; Belanger \& Havkin-Frenkel 2011; Varela Quirós 2011). Historical, genetic and phylogenetic data are insufficient to decide whether $V$. sotoarenasii sp. nov. derived from natural or introduced populations of $V$. planifolia, nor how and when the radiation occurred. 
Table 6. Characters differentiating Vanilla sotoarenasii M.Pignal, Azofeifa-Bolaños \& Grisoni sp. nov. from related species.

\begin{tabular}{|c|c|c|c|}
\hline & V. planifolia & $V_{0} \times$ tahitensis & V. sotoarenasii sp. nov. \\
\hline Leaf shape & elliptic to oblong & $\begin{array}{l}\text { narrowly oblong to } \\
\text { lanceolate }\end{array}$ & elliptic to obovate \\
\hline Leaf length & more than $14 \mathrm{~cm}$ long & more than $14 \mathrm{~cm}$ long & less than $12 \mathrm{~cm}$ long \\
\hline Leaf length/width ratio & $\begin{array}{l}\text { less than } 4 \text { times } \\
\text { as long as wide }\end{array}$ & $\begin{array}{l}\text { more than } 4 \text { times } \\
\text { as long as wide }\end{array}$ & $\begin{array}{c}\text { about } 3 \text { times } \\
\text { as long as wide }\end{array}$ \\
\hline $\begin{array}{c}\text { Sepal size } \\
\text { (length } \times \text { width) }\end{array}$ & more than $55 \times 10 \mathrm{~mm}$ & more than $55 \times 10 \mathrm{~mm}$ & no more than $53 \times 8 \mathrm{~mm}$ \\
\hline Fruit section & $\begin{array}{l}\text { triangular, } \\
\text { generally dehiscent }\end{array}$ & $\begin{array}{c}\text { triangular, } \\
\text { generally indehiscent }\end{array}$ & $\begin{array}{l}\text { rounded, } \\
\text { indehiscent }\end{array}$ \\
\hline
\end{tabular}

Orchid species are often interfertile, which allows them to create interspecific and even intergeneric fertile hybrids. Many interspecific hybrids between species of Vanilla have been produced in the last decades by botanists and agronomists (Knudson 1950; Theis \& Jiménez 1957; Divakaran et al. 2006). In nature, however, interspecific hybrids are prevented by reproductive barriers that result primarily from the inability of pollinators to transfer pollen from one species to another. Within the limits of our sampling, we have never observed intermediary types, at the genetic or morphological level, in the Limón area, which suggests that a reproductive barrier may exist between $V$. planifolia and $V$. sotoarenasii sp. nov. Indeed, in the case of sympatric populations of the two very closely related species $V$. barbellata Rchb.f. and $V$. dilloniana Correll, having synchronous flowering and the same pollinator in western Puerto Rico, intermediary types were observed, demonstrating natural interspecific hybridizations (Nielsen 2000). We hypothesize that the differences in flower morphology observed between $V$. planifolia and $V$. sotoarenasii sp. nov. impede gene flow from one species to another, which enhanced the radiation of the population in Limón. Vanilla pollination is bee-dependent (Ackerman 1986; Gigant et al. 2011) and flower size difference is likely to constitute a reproductive barrier between species by selecting compatible pollinators. This has been observed for instance in Peru where, due to their small size, the Mellipona bees did not remove pollen when visiting $V$. grandiflora Lindl. flowers, and therefore did not contribute to its pollination (Lubinsky et al. 2006). Given the significant size reduction of the flowers of $V$. sotoarenasii sp. nov. compared to those of $V$. planifolia, it is unlikely that a bee capable of pollinating one of the two species would be able to pollinate the other. In addition to size compatibility, the probability of pollinator visits is frequently increased by the aromatic metabolites emitted by orchid flowers, which act as bee attractants (Ackerman 1986; Pansarin \& Pansarin 2014). This is particularly important for vanilla flowers that are open a single day, which reduces the chances of pollen-pollinator encounter. Analysis of the volatile compounds emitted by flowers from various Vanilla species (unpublished data) has shown in particular that in V. planifolia $(\mathrm{n}=4)$ the major compounds are a hydrocarbon monoterpene, $(\mathrm{E})$ - $\beta$-ocimene (representing $17.10 \pm 14.08 \%$ of all detected compounds), and an aromatic compound, 2,6-bis (1,1-dimethylethyl)4-(1-oxopropyl) phenol $(11.59 \pm 8,04 \%)$, while in $V$. sotoarenasii sp. nov. $(\mathrm{n}=1)$, only $(\mathrm{E})$ - $\beta$-ocimene was predominantly found $(63.26 \%)$. This difference in the nature of volatile emissions between the two species could also contribute to the specificity of the pollinators visiting the flowers. Furthermore, the earlier flowering of $V$. sotoarenasii sp. nov. compared to $V$. planifolia may also contribute to favor self or geitonogamous pollination as well as provide greater reproductive success to $V$. sotoarenasii sp. nov., as pointed out for non-rewarding orchids (Jersáková et al. 2006; Sun et al. 2009).

All these factors hindering gene flow between populations of $V$. sotoarenasii sp. nov. and $V$. planifolia may account for the radiation that led to the emergence of $V$. sotoarenasii sp. nov., a species that is genetically, morphologically, and biochemically distinct from $V$. planifolia. 
Finally, given its original aromatic content combining vanilyl and anisic notes, its high level of resistance (at least for CR0068) to the Fusarium root rot of vanilla (Koyyappurath et al. 2015), and its early and abundant flowering in culture, $V$. sotoarenasii sp. nov. could be a promising genitor for breeding programs aiming to produce new vanilla varieties for the agroindustry.

\section{Acknowledgements}

The authors are grateful to the National Council for Scientific and Technological Research of Costa Rica (CONICIT) for the financial support to conduct the collecting missions in Costa Rica, and to the Distance Education University of Costa Rica (UNED) for supporting the MSc work of the first author. The molecular genotyping and phylogenetic analyses were partly funded by the Vanitax (ANR Bibliothèque du Vivant) and the VaBiome (EraNet-NetBiome) projects. The authors would like to warmly thank M. Alain Rongier, Pierre Poulain, Jean-Paul Brixtel and the municipality of Cherbourgen-Cotentin (France) for allowing access to the material conserved in the Parc Emmanuel Liais, Ana Barquero of INISEFOR-UNA for providing plant material, Pr. Thomas Petit and colleagues from the University Institute of Technology of Saint Pierre (La Réunion) for facilitating HPLC analyses in their lab, and Marc Jeanson from P, Muséum national d'Histoire naturelle (Paris).

\section{References}

Ackerman J.D. 1986. Mechanisms and evolution of food-deceptive pollination systems in orchids. Lindleyana 1: 108-113.

Agardh C.A., Holmberg L.P. \& Lundstrom P.M. 1825. Classes Plantarum. Literis Berlingianis, Lundae [Lund, Sweden].

Ames O. 1934. An addition to the genus Vanilla. Harvard University Botanical Museum Leaflet 2: $101-102$.

Andrews H.C. 1808. Vanilla planifolia. Botanist's Repository 8: 538.

Archila F. \& Chiron G.R. 2012. Addition à la flore du Guatemala: Vanilla esquipulensis (Orchidaceae), espèce des forêts xérophytes. Richardiana 13: 3-12.

Azofeifa-Bolaños J.B., Paniagua-Vásquez A. \& Garcia-Garcia J.A. 2014. Importancia y desafíos de la conservación de Vanilla spp. (Orchidaceae) en Costa Rica. Agronomía Mesoamericana 25: 189-202. http://dx.doi.org/10.15517/am.v25i1.14220

Belanger F.C. \& Havkin-Frenkel D. 2011. Molecular analysis of a Vanilla hybrid cultivated in Costa Rica. In: Havkin-Frenkel D. \& Belanger F.C. (eds) Handbook of Vanilla Science and Technology: 256263. Wiley-Blackwell, Chichester, United Kingdom.

Besse P. (ed.) 2014. Molecular Plant Taxonomy - Methods and Protocols. Humana Press (Springer), New York.

Blume C.L.V. 1835. Rumphia, sive, Commentationes botanica imprimis de plantis Indice Orientalis: tum penitus incognitis tum qua in libris Rheedii, Rumphi, Roxburghii, Wallichii aliorum recensentur / scripsit C.L. Blume cognomine Rumphius. Vol. 1: 196. Leiden. Available from http://biodiversitylibrary. org/page/41039881 [accessed 18 Jan. 2017].

Bory S., Lubinsky P., Risterucci A.-M., Noyer J.-L., Grisoni M., Duval M.-F. \& Besse P. 2008. Patterns of introduction and diversification of Vanilla planifolia (Orchidaceae) in Reunion Island (Indian Ocean). American Journal of Botany 95: 805-815. http://dx.doi.org/10.3732/ajb.2007332

Bouétard A., Lefeuvre P., Gigant R., Bory S., Pignal M., Besse P. \& Grisoni M. 2010. Evidence of transoceanic dispersion of the genus Vanilla based on plastid DNA phylogenetic analysis. Molecular Phylogenetics and Evolution 55: 621-630. http://dx.doi.org/10.1016/j.ympev.2010.01.021 
Brunschwig C., Collard F.X., Bianchini J.P. \& Raharivelomanana P. 2009. Evaluation of chemical variability of cured vanilla beans (Vanilla tahitensis and Vanilla planifolia). Natural Products Communications 4: 1393-1400.

Cameron K.M. 2009. On the value of nuclear and mitochondrial gene sequences for reconstructing the phylogeny of vanilloid orchids (Vanilloideae, Orchidaceae). Annals of Botany 104: 377-385. http:// dx.doi.org/10.1093/aob/mcp024

Cameron K.M. 2010. Vanilloid orchids. In: Odoux E. \& Grisoni M. (eds) Vanilla: 1-13. CRC Press, Boca Raton, FL.

Cameron K.M. 2011. Vanilla phylogeny and classification. In: Havkin-Frenkel D. \& Belanger F.C. (eds) Handbook of Vanilla Science and Technology: 241-255. Wiley-Blackwell, Chichester, United Kingdom.

Costantin D. \& Bois J. 1915. Sur trois types de vanilles commerciales de Tahiti. Comptes Rendus de l'Académie des Sciences de Paris 161: 196-202.

Darriba D., Taboada G., Doallo R. \& Posada D. 2012. jModelTest 2: more models, new heuristics and parallel computing. Nature Methods 9: 772. http://dx.doi.org/10.1038/nmeth.2109

Divakaran M., Babu K.N. \& Peter K.V. 2006. Conservation of Vanilla species in vitro. Scientia Horticulturae 110: 175-180. http://dx.doi.org/10.1016/j.scienta.2006.07.003

Gigant R., Bory S., Grisoni M. \& Besse P. 2011. Biodiversity and evolution in the Vanilla genus. In: Grillo O. \& Venora G. (eds) The Dynamical Processes of Biodiversity: Case Studies of Evolution and Spatial Distribution. InTech, Rijeka, Croatia.

Guindon S., Gascuel O. \& Rannala B. 2003. A simple, fast and accurate method to estimate large phylogenies by maximum-likelihood. Systematic Biology 52: 696-704. http://dx.doi. org/10.1080/10635150390235520

Hall T.A. 1999. BioEdit: a user-friendly biological sequence alignment editor and analysis program for Windows 95/98/NT. Nucleic Acids Symposium Series 41: 95-98.

Heller A.H. \& Hawkes A.D. 1966. Nicaraguan orchid studies. Phytologia 14: 19-20.

Hoehne F.C. 1910. Botânica: I. Bromeliaceas, Pontederiaceas, Liliaceas, Amaryllidaceas, Iridaceas, Orchidaceas, Aristolochiaceas, Droseraceas e Passifloraceas. Commissão das Linhas Telegraficas Estratégicas, Matto Grosso e Amazonas 5: 1-71.

Hoehne F.C. 1944. Vanilla trigonocarpa. Arquivos de Botânica do Estado de São Paulo 1 (6): 126-127.

Hoehne F.C. 1950. Algunas novidades da flora do Brasil austro-oriental de entre Orchidaceas e Convolvulaceas. Arquivos de Botânica do Estado de São Paulo 2 (5): 105-110.

Hollingsworth P.M., Forrest L.L., Spouge J.L., Hajibabaei M., Ratnasingham S., van der Bank M., Chase M.W., Cowan R.S., Erickson D.L., Fazekas A.J., Graham S.W., James K.E., Kim K.-J., Kress W.J., Schneider H., Van AlphenStahl J., Barrett S.C.H., van den Berg C., Bogarin D., Burgess K.S., Cameron K.M., Carine M., Chacón J., Clark A., Clarkson J.J., Conrad F., Devey D.S., Ford C.S., Hedderson T.A.J., Hollingsworth M.L., Husband B.C., Kelly L.J., Kesanakurti P.R., Kim J.S., Kim Y.-D., Lahaye R., Lee H.-L., Long D.G., Madriñán S., Maurin O., Meusnier I., Newmaster S.G., Park C.-W., Percy D.M., Petersen G., Richardson J.E., Salazar G.A., Savolainen V., Seberg O., Wilkinson M.J., Yi D.-K. \& Little D.P. 2009. A DNA barcode for land plants. Proceedings of the National Academy of Sciences 106: 12794-12797. http://dx.doi.org/10.1073/pnas.0905845106

Hothorn T., Bretz F. \& Westfall P. 2008. Simultaneous inference in general parametric models. Biometrical Journal 50: 346-336. http://dx.doi.org/10.1002/bimj.200810425 
IUCN 2012. IUCN Red List Categories and Criteria: Version 3.1. Second edition. IUCN, Gland, Switzerland and Cambridge, United Kingdom.

Jersáková J., Johnson S. \& Kindlmann P. 2006. Mechanisms and evolution of deceptive pollination in orchids. Biological Reviews of the Cambridge Philosophical Society 81: 219-235. http://dx.doi. org/10.1017/S1464793105006986

Jussieu A.-L. de 1789. Genera Plantarum, Secundum Ordines Naturales Disposita, juxta Methodum in Horto Regio Parisiensi Exaratam. Herissant, Paris. Available from http://biodiversitylibrary.org/ page/5437140 [accessed 12 Jan. 2017].

Knudson L. 1950. Germination of seeds of vanilla. American Journal of Botany 37: 241-247.

Koyyappurath S., Conéjéro G., Dijoux J.B., Lapeyre Montes F., Jade K., Chiroleu F., Gatineau F., Verdeil J.L., Besse P. \& Grisoni M. 2015. Differential responses of vanilla accessions to root rot and colonization by Fusarium oxysporum f. sp. radicis-vanillae. Frontiers in Plant Science 6. http://dx.doi. org/10.3389/fpls.2015.01125

Kumar S., Stecher G. \& Tamura K. 2016. MEGA7: Molecular Evolutionary Genetics Analysis version 7.0 for bigger datasets. Molecular Biology and Evolution 33 (7): 1870-1874. http://dx.doi.org/10.1093/ molbev/msw054

Link H.F. 1829. Handbuch zur Erkennung der nutzbarsten und am häufigsten vorkommenden Gewächse. Haude und Spener, Berlin.

Lubinsky P., Van Dam M. \& Van Dam A. 2006. Pollination of Vanilla and evolution in Orchidaceae. Lindleyana 75: 926-929.

Lubinsky P., Cameron K.M., Molina M.C., Wong M., Lepers-Andrzejewski S., Gómez-Pompa A. \& Kim S.-C. 2008. Neotropical roots of a Polynesian spice: the hybrid origin of Tahitian vanilla, Vanilla tahitensis (Orchidaceae). American Journal of Botany 95: 1040-1047. http://dx.doi.org/10.3732/ ajb.0800067

Maruenda H., Vico M.D.L., Householder J.E., Janovec J.P., Cañari C., Naka A. \& Gonzalez A.E. 2013. Exploration of Vanilla pompona from the Peruvian Amazon as a potential source of vanilla essence: quantification of phenolics by HPLC-DAD. Food Chemistry 138: 161-167. http://dx.doi.org/10.1016/j. foodchem.2012.10.037

Miller P. 1754. The Gardeners Dictionary: Containing the Methods of Cultivating and Improving all Sorts of Trees, Plants, and Flowers for the Kitchen, Fruit and Pleasure Gardens and also those which are used in Medecine. Fourth edition. J. \& J. Rivington, London.

Molineros-Hurtado F., González-Mina R.T., Flanagan N.S. \& Otero J.T. 2014. Vanilla rivasii (Orchidaceae), a new species from the Colombian Pacific region. Lankesteriana 13: 353-357.

Moore J.W. 1933. New and critical plants from Raiatea. Bulletin of the Bernice P. Bishop Museum 102: $1-53$.

Nielsen L.R. 2000. Natural hybridization between Vanilla claviculata (W.Wright) Sw. and V. barbellata Rchb.f. (Orchidaceae): genetic, morphological, and pollination experimental data. Botanical Journal of the Linnean Society 133: 285-302. http://dx.doi.org/10.1111/j.1095-8339.2000.tb01547.x

Pabst G.F.J. 1975. Vanilla dungsii. Bradea 2: 49.

Palama T.L., Khatib A., Choi Y.H., Payet B., Fock I., Verpoorte R. \& Kodja H. 2009. Metabolic changes in different developmental stages of Vanilla planifolia pods. Journal of Agricultural and Food Chemistry 57: 7651-7658. http://dx.doi.org/10.1021/jf901508f 
Pansarin E.R. \& Pansarin L.M. 2014. Floral biology of two Vanilloideae (Orchidaceae) primarily adapted to pollination by euglossine bees. Plant Biology 16: 1104-1113. http://dx.doi.org/10.1111/plb.12160

Pansarin E.R., Salatino A., Pansarin L.M. \& Sazima M. 2012. Pollination systems in Pogonieae (Orchidaceae: Vanilloideae): A hypothesis of evolution among reward and rewardless flowers. Flora - Morphology, Distribution, Functional Ecology of Plants 207: 849-861. http://dx.doi.org/10.1016/j. flora.2012.09.011

Pérez-Silva A., Odoux E., Brat P., Ribeyre F., Rodriguez-Jimenes G., Robles-Olvera V., GarcíaAlvarado M.A. \& Günata Z. 2006. GC-MS and GC-olfactometry analysis of aroma compounds in a representative organic aroma extract from cured vanilla (Vanilla planifolia G. Jackson) beans. Food Chemistry 99: 728-735. http://dx.doi.org/10.1016/j.foodchem.2005.08.050

Pérez Silva A., Gunata Z., Lepoutre J.-P. \& Odoux E. 2011. New insight on the genesis and fate of odor-active compounds in vanilla beans (Vanilla planifolia G. Jackson) during traditional curing. Food Research International 44: 2930-2937. http://dx.doi.org/10.1016/j.foodres.2011.06.048

Portères R. 1953. Le potentiel de variation clonale de Vanilla tahitensis J. W. Moore. L'agronomie Tropicale 8: 639-640.

Portères R. 1954. Le genre Vanilla et ses espèces. In: G. Bouriquet (ed.) Le Vanillier et la Vanille dans le Monde: 94-290. Editions Paul Lechevalier, Paris.

Presl C.B. von 1827. Reliquiae Haenkeanae. J.G. Calve, Prague, Czech Republic.

R Core Team 2013. R: A language and environment for statistical computing. R Foundation for Statistical Computing, Vienna.

Ramírez S.R., Gravendeel B., Singer R.B., Marshall C.R. \& Pierce N.E. 2007. Dating the origin of the Orchidaceae from a fossil orchid with its pollinator. Nature 448: 1042-1045. http://dx.doi.org/10.1038/ $\underline{\text { nature } 06039}$

Reichenbach F.H.G. 1865. Vanilla phaeantha. Flora 48: 274.

Reyes-López D., Flores-Jiménez A., Huerta-Lara M., Kelso-Bucio H.A., Avendaño-Arrazate C.H., Lobato-Ortiz R., Aragón-García A. \& López-Olguín J.F. 2014. Variación morfométrica de fruto y semilla en cuatro especies del género Vanilla. Ecosistemas y Recursos Agropecuarios 1: 205-218.

Rolfe R.A. 1895. Vanillas of commerce. Bulletin of Miscellaneous Information, Royal Botanic Gardens, Kew 1895: 169-178. Available from http://biodiversitylibrary.org/page/40984721 [accessed 12 Jan. 2017].

Rolfe R.A. 1899. New Orchids. - Decades 23 and 24. Bulletin of Miscellaneous Information, Royal Botanic Gardens, Kew 1899: 126-133. Available from http://biodiversitylibrary.org/page/40848484 [accessed 12 Jan. 2017].

Roux-Cuvelier M. \& Grisoni M. 2010. Conservation and movement of Vanilla germplasm. In: Odoux E. \& Grisoni M. (eds) Vanilla: 31-41. CRC Press, Boca Raton, FL.

Sambin A. \& Chiron G.R. 2015. Deux nouvelles espèces de Vanilla (Orchidaceae) de Guyane française. Richardiana 15: 306-316.

Schiede C.J.W. 1829. Botanische Berichte aus Mexico. Linnaea 4: 574-604.

Soto Arenas M.A. \& Cribb P. 2010. A new infrageneric classification and synopsis of the genus Vanilla Plum. ex Mill. (Orchidaceae: Vanillinae). Lankesteriana 9: 355-398. 
Soto Arenas M.A. \& Dressler R.L. 2010. A revision of the Mexican and Central American species of Vanilla Plumier ex Miller with a characterization of their ITS region of the nuclear ribosomal DNA. Lankesteriana 9: 285-354.

Sun H.-Q., Cheng J., Zhang F.-M., Luo Y.-B. \& Ge S. 2009. Reproductive success of non-rewarding Cypripedium japonicum benefits from low spatial dispersion pattern and asynchronous flowering. Annals of Botany 103: 1227-1237. http://dx.doi.org/10.1093/aob/mcp066

Sun Y., Skinner D.Z., Liang G.H. \& Hulbert S.H. 1994. Phylogenetic analysis of Sorghum and related taxa using internal transcribed spacers of nuclear ribosomal DNA. Theoretical and Applied Genetics 89: 26-32. http://dx.doi.org/10.1007/BF00226978

Szlachetko D.L. 1995. Systema Orchidalium. W. Szafer Institute of Botany, Polish Academy of Sciences, Kraków.

Takhtajan A.L. 1967. Sistema i Filogeniia Tsvetkovykh Rastenii (Systema et Phylogenia Magnoliophytorum). Soviet Science Press, Moscow.

Theis T. \& Jiménez T.A. 1957. A Vanilla hybrid resistant to Fusarium root rot. Phytopathology 47: $578-581$.

Thiers B. Continuously updated. Index Herbariorum, a Global Directory of Public Herbaria and Associated Staff. Available from http://sweetgum.nybg.org/ih/ [accessed Aug. 2016].

Varela Quirós E. 2011. Vanilla production in Costa Rica. In: Havkin-Frenkel D. \& Belanger F.C. (eds) Handbook of Vanilla Science and Technology: 40-49. Wiley-Blackwell, Chichester, United Kingdom.

Xu S., Li D., Li J., Xiang X., Jin W., Huang W., Jin X. \& Huang L. 2015. Evaluation of the DNA barcodes in Dendrobium (Orchidaceae) from mainland Asia. PLOS ONE 10: e0115168. http://dx.doi. org/10.1371/journal.pone.0115168

Manuscript received: 18 March 2016

Manuscript accepted: 2 September 2016

Published on: 22 February 2017

Guest editors: Line Le Gall, Frédéric Delsuc, Stéphane Hourdez, Guillaume Lecointre

and Jean-Yves Rasplus

Desk editor: Danny Eibye-Jacobsen

Printed versions of all papers are also deposited in the libraries of the institutes that are members of the EJT consortium: Muséum national d'Histoire naturelle, Paris, France; Botanic Garden Meise, Belgium; Royal Museum for Central Africa, Tervuren, Belgium; Natural History Museum, London, United Kingdom; Royal Belgian Institute of Natural Sciences, Brussels, Belgium; Natural History Museum of Denmark, Copenhagen, Denmark; Naturalis Biodiversity Center, Leiden, the Netherlands. 